Article

\title{
Life Cycle Assessment of Variable Rate Fertilizer Application in a Pear Orchard
}

\author{
Anna Vatsanidou ${ }^{1, *} \mathbb{B}$, Spyros Fountas ${ }^{2}$, Vasileios Liakos ${ }^{3}$, George Nanos ${ }^{1}$, \\ Nikolaos Katsoulas ${ }^{1}$ (D) and Theofanis Gemtos ${ }^{1}$ \\ 1 Department of Agriculture Crop Production and Rural Environment, University of Thessaly, \\ 38446 Volos, Greece; gnanos@uth.gr (G.N.); nkatsoul@uth.gr (N.K.); gemtos@uth.gr (T.G.) \\ 2 Department of Natural Resources Management and Rural Environment, Agricultural University of Athens, \\ 11855 Athens, Greece; sfountas@aua.gr \\ 3 Department of Crop and Soil Sciences, University of Georgia, Athens, GA 30602, USA; vliakos@uga.edu \\ * Correspondence: vatsanidou@gmail.com
}

Received: 29 July 2020; Accepted: 19 August 2020; Published: 25 August 2020

check for updates

\begin{abstract}
Precision Agriculture (PA) is a crop site-specific management system that aims for sustainability, adopting agricultural practices more friendly to the environment, like the variable rate application (VRA) technique. Many studies have dealt with the effectiveness of VRA to reduce nitrogen $(\mathrm{N})$ fertilizer, while achieving increased profit and productivity. However, only limited attention was given to VRA's environmental impact. In this study an International Organization for Standardization (ISO) based Life Cycle Assessment (LCA) performed to identify the environmental effects of N VRA on a small pear orchard, compared to the conventional uniform application. A Cradle to Gate system with a functional unit (FU) of $1 \mathrm{~kg}$ of pears was analyzed including high quality primary data of two productive years, including also the non-productive years, as well as all the emissions during pear growing and the supply chains of all inputs, projecting them to the lifespan of the orchard. A methodology was adopted, modelling individual years and averaging over the orchard's lifetime. Results showed that Climate change, Water scarcity, Fossil fuels and Particulate formation were the most contributing impact categories to the overall environmental impact of the pear orchard lifespan, where climate change and particulates were largely determined by $\mathrm{CO}_{2}, \mathrm{~N}_{2} \mathrm{O}$, and $\mathrm{NH}_{3}$ emissions to the air from fertilizer production and application, and as $\mathrm{CO}_{2}$ from tractor use. Concerning fertilization practice, when VRA was combined with a high yield year, this resulted in significantly reduced environmental impact. LCA evaluating an alternative fertilizer management system in a Greek pear orchard revealed the environmental impact reduction potential of that system.
\end{abstract}

Keywords: site specific input management; nitrogen variable rate application; life cycle assessment of pear orchard; environmental impact of precision agriculture; Pyrus communis L.

\section{Introduction}

Worldwide interest for humans' impact on the environment has initiated a great number of research studies concerning the environmental impact of several production sectors. In the agricultural sector a lot of studies have been conducted to quantify the intensive nature of agricultural practices with regard to the environmental impacts they cause like, loss of soil organic matter and carbon sequestration [1,2], soil erosion [3-5], water depletion [6,7], human toxicity [8] and deterioration of the environment (eutrophication, ecotoxicity, soil degradation and acidification) due to excessive use of external nutrients (mainly nitrogen, N) and pesticides [9-12]. Alternative cultivation practices in production systems such as organic and integrated farming, are often characterized as low-input cropping systems that are meant to reduce the environmental impacts associated with food production, 
presenting in most cases benefits that are offset by lower yields [13]. Therefore, highly eco-efficient cropping systems require the application of optimum instead of minimum quantities of external input [14]. Precision Agriculture (PA) currently is considered a powerful solution to mitigate the environmental impact of farming systems [15], assisting farmers in the precise and optimized use of inputs adapted to the apparent plant status, consequently leading to reduced costs and environmental impact [16].

Variable rate application (VRA) is the basic technique of PA, aiming to perform site specific input management. The literature indicate that VRA of fertilizer has proven to be one of the most effective methods for achieving relatively high yields or of maintaining yields, while using a reduced amount of fertilizer, due to better fertilizer use efficiency of different crops [17-20]. Spatial variability in yields has been considered as a useful indicator to determine variable rate nutrient management [21]. According to Heege (2013) [22], if yields are recorded during harvest over small areas and georeferenced at a very fine spatial resolution, then nutrient removal for these small areas can be determined and the nutrients can be applied in a site-specific way using the VRA technique. Basso et al. (2016) [23], based on the analysis of yield maps from previous harvests of cover crops, applied N VRA which resulted in lower $\mathrm{N}$ leaching when compared to uniform $\mathrm{N}$ fertilization, while Frits $\mathrm{K}$. van Evert et al. (2017) [24] applied VRA fertilizer in olives, which indicated a strong reduction in nutrient use. Likewise, Vatsanidou et al. (2017) [19] performed two year N VRA prescription maps in a small pear orchard based on the replacement of the nutrients removed by the crop, resulting in $56 \%$ and $50 \%$ reduction of N fertilizer compared to uniform application. Similarly, Liakos et al. (2020) [20], in a two year study on an apple orchard applied $59.6 \%$ and $63.4 \%$ less fertilizer using VRA technique with less than a $4 \%$ difference in yield, while reducing costs by $2.3 \%$ and $7.6 \%$.

Thus, site specific management using VRA offers the prospect of improving farm productivity and profitability, as well as indicating a reduction of the environmental impacts from farming [25]. Research on the impact of site-specific $\mathrm{N}$ management on the environment commenced some time ago with several studies in arable crops. Nitrogen nitrate $\left(\mathrm{NO}_{3}-\mathrm{N}\right)$ leaching was reduced or $\mathrm{N}$ use efficiency (NUE) increased (NUE is generally defined as the grain yield produced per unit of $\mathrm{N}$ available from soil and fertilizer), when variable rate technology was used [26-28]. More recent studies evaluated the $\mathrm{NO}_{3}-\mathrm{N}$, nitrous oxide $\left(\mathrm{N}_{2} \mathrm{O}\right)$ and ammonia $\left(\mathrm{NH}_{3}\right)$ air emissions of VRA fertilizer on maize $[18,29]$ and on rice [15]. However, only a few studies concerned the environmental impact of VRA techniques in orchards [30].

Life Cycle Assessment (LCA) is generally considered the most appropriate tool to support the environmental assessment of agricultural products from primary production to consumption and end-of-life treatment. LCA is a methodological tool which quantifies and assesses the emissions, resources consumed, and pressures on health and the environment that can be attributed to different products or processes over their entire life cycle, i.e., from the materials used for production to the end of the product [31]. Several recent developments, like the harmonization of existing guidelines for environmental footprints (of food Sustainable Consumption and Production Roundtable, Leap partnership and Environmental footprint project), have contributed to support the application of LCA to agro-products, where applying LCA appears to be more challenging than for other types of products, since it is difficult to reach a consensus within the agricultural sector (allocation of deforestation to land activities, assessment of agricultural emission profiles, regionalization of water scarcity assessments etc.) [32]. In the fruit sector, the majority of LCA studies have been conducted giving a preference to the evaluation of crop environmental performance and the agricultural practices performed. Mila i Canals et al. (2006) [33] performed both a contribution and an uncertainty analysis of the agricultural practices in an apple orchard, identified which agricultural processes contributed the most ("hot-spot") to the environmental impact of apple production, revealing that $50 \%$ of the highest impact categories were due to energy-related emissions, while fertilizer and pesticide application and production also generated an important share of many impact categories, which also agreed with other studies in citrus, fresh pineapple and peaches [34-37]. The three latter orchards indicated a significant 
use of water consumption resulting in the high impact of the irrigation process. Other categories of studies aimed to reveal that carbon footprint (CF) (based on life-cycle approaches), fertilization and the use of agricultural machinery were the most important contributors to the total of greenhouse gas emissions (GHG) emissions, while more fossil energy was used for irrigation and machinery [38]. Likewise, in a recent study Balafoutis et al. (2017) [30] found that the most significant activity regarding GHG emissions was fertilizer production and application in both conventional and precision viticulture practices.

This study describes a complete environmental impact assessment using the LCA methodology, following the basic steps of a life cycle analysis according to the International Organization for Standardization, ISO standards for LCA 14040 and 14044 (2006) [39,40]. The main objective of the study was to develop the environmental profile of a small pear orchard considering the whole lifetime of the orchard under different fertilization practices: uniform application and VRA. No similar comparative LCA research has been made until now to evaluate the environmental impact of pear production, especially when the N VRA technique is used. Only recently Bacenetti et al. (2020) [15], performed a comparative LCA study of uniform and VRA fertilizer in maize. A similar study compared these two practices in a life cycle-based CF analysis by Balafoutis et al. (2017) [30]. The software SimaPro 8.0.4.30 (PRé Consultants, Amersfoort, NL, USA) [41] was adopted to analyze all the Life Cycle Impact Assessment (LCIA) steps, characterization, normalization and weighting.

\section{Materials and Methods}

\subsection{LCA Methodology}

In ISO 14040 (2006) [39] LCA is defined as the "compilation and evaluation of the inputs, outputs and potential environmental impacts of a product system throughout its life cycle". LCA is an approach which is structured around a functional unit (FU). This FU defines what is being studied. All subsequent analyses are then related to that $\mathrm{FU}$, as all inputs and outputs in the Life Cycle Inventory (LCI) and consequently the LCIA. LCA is an iterative tool (Figure 1). Each phase of an LCA use the results of other phases. The iterative approach within and between the phases contributes to the comprehensiveness and consistency of the study and the reported results. Due to the inherent complexity in LCA, transparency is an important guiding principle in executing LCAs, in order to ensure a proper interpretation of the results. LCA considers all attributes or aspects of natural environment, human health and resources. By considering all attributes and aspects within one study, potential trade-offs can be identified and assessed.

Four different phases of LCA are distinguished:

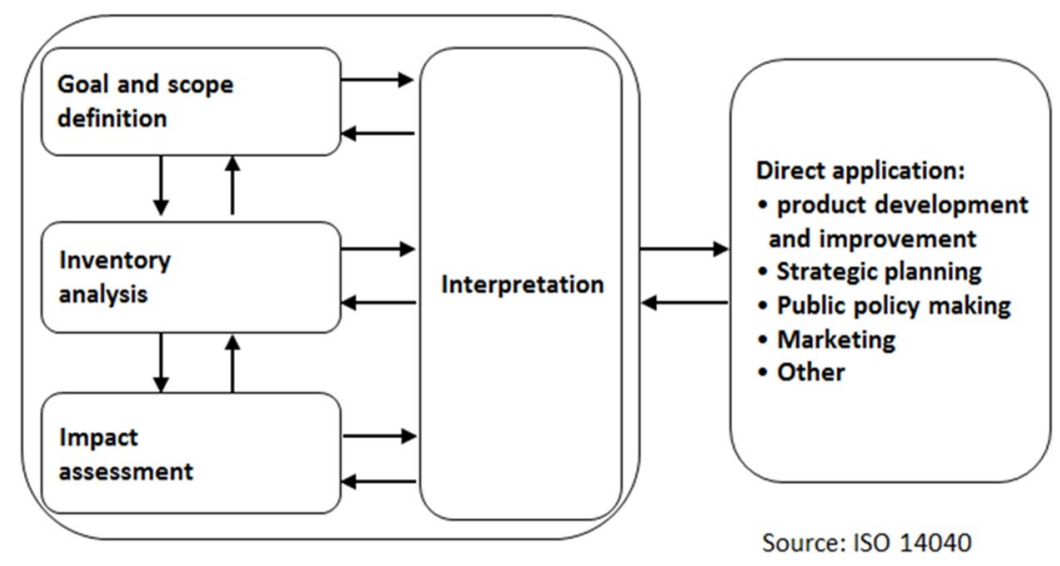

Figure 1. Life Cycle Assessment (LCA) phases.

LCA studies comprise four phases: (1) goal and scope definition, (2) inventory analysis, (3) impact assessment, and (4) interpretation. 


\subsection{Goal and Scope}

The current study was carried out in a 0.55 ha pear (Pyrus communis L.) cv. 'Coscia' orchard on flat terrain in Tirnavos, located in the Thessaly region, Central Greece (WGS84: $22^{\circ} 16^{\prime} 80^{\prime \prime} \mathrm{E}$, $\left.39^{\circ} 44^{\prime} 10^{\prime \prime} \mathrm{N}\right)$. The orchard was planted in 1994 with the early maturing pear cultivar Coscia grafted onto BA29 quince rootstock. The soil was silt-sandy, light soil [42], presenting high variations of organic matter content (low to high values) and phosphorus (low to adequate), while $\mathrm{K}$ and $\mathrm{CaCO}_{3}$ were under the adequate values. Moreover, soil $\mathrm{pH}$ ranged from 7.43 to 8.67 , indicating an alkaline soil. Crop management was implemented conventionally and allowed a complete control of weeds, pests and diseases, while fertilization was applied in several doses during the growing season. Coscia are harvested after mid-July, before they reach the fully mature stage, due to their susceptibility to core breakdown disorder. Coscia pear fruits have a tear-drop shape with strong flavor and are juicy enough to be included in the most tasteful pear varieties that go straight to market without being stored in refrigerators. Pears require a substantial number of inputs to achieve satisfactory yield and quality. Moreover, environmental problems like nitrate pollution of the underground aquifer were present in the area of Tirnavos, where the orchard was located.

The main concept of the LCA study was used in order to answer questions like, "Which environmental impacts occur when agricultural practices, like fertilization, are applied in a pear orchard?, Does VRA of N influence in any way the environmental burden?, How do these environmental impacts directly and indirectly affect human health, the environment and the resources use?, Which of these environmental impacts affects more, i.e., what are the hotspots in the study, and how we can limit their negative impact?". The main objective of the study was to develop the environmental profile of the particular pear orchard under different agricultural practices. More specifically, the ultimate aim was to reveal and compare the environmental impacts of using different $\mathrm{N}$ fertilizer application techniques: uniform and VRA. Many environmental research studies have focused on $\mathrm{N}$ application on several crops. This probably was due to the fact that local over-fertilization may enhance nitrate leaching and thus decrease ground water quality. Over fertilization may also induce $\mathrm{NH}_{3}$ volatilization and $\mathrm{N}_{2} \mathrm{O}$ emissions, leading to potential environmental acidification and increased GHG emissions. An additional motivation for studying the environmental effects of fertilization is the high cost of $\mathrm{N}$ fertilizers. Furthermore, there was a need to investigate the magnitude of the impacts induced from fertilizer usage compared to the impacts of other inputs in the system, like the use of pesticides and the production phase of all the agrochemicals and the energy consumption represented by diesel use in the different agricultural processes. Another objective was to suggest improvements and to detect research needs.

The goal was to perform a multiple impact category LCA following the ISO standards for LCA 14040 and 14044 as closely as possible.

\subsubsection{Functional Unit}

According to ISO standards, FU is defined as the main function of the system expressed in quantitative terms $[39,40]$. In the present study FU was defined as $1 \mathrm{~kg}$ of pears, unpackaged, at the farm gate. This means that the LCA study was a cradle-to-farm gate study, which means that was an assessment of a partial life cycle of a product, from the extraction of raw materials (cradle) up to the production of the product and harvesting at the "farm gate". A mass based FU was chosen since it is regarded adequate when only analyzing the agricultural stages of the life cycle of fresh product for descriptive purposes [33].

\subsubsection{System Boundaries}

A "Cradle to Farm Gate" system boundary (Figure 2) with a FU of $1 \mathrm{~kg}$ of export quality pears was analyzed including high quality primary field data, as well as all the emissions during pear growing and the supply chains of all inputs. In particular, the following stages of the production process were considered: (i) extraction of raw materials (e.g., fossil fuels, metals and minerals); (ii) in 
the case of capital goods (or ancillaries), the production, use and maintenance phase of the machinery were analyzed, as well as the farming infrastructure (e.g., buildings, irrigation infrastructure, etc.); (iii) production of the different inputs (fertilizers, pesticides, electricity, diesel, etc.); (iv) emissions related to the use of input factors (e.g., emissions due to fertilizer application, diesel fuel emissions related to diesel combustion in the tractor engine, etc.).

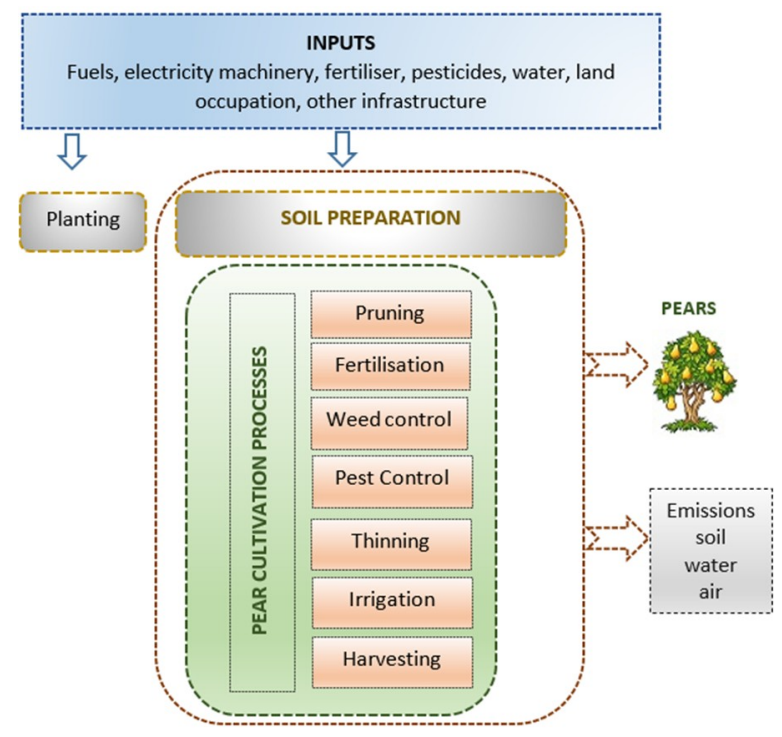

Figure 2. System boundary for pear cultivation.

The soil preparation before planting was accounted for in the first 3 years of growth of the pear orchard. The nursery process and planting were not included in the system under study mainly due to the lack of reliable data [37] as well as due to the minor contribution they had [33,43]. The carbon dioxide $\mathrm{CO}_{2}$ uptake of the trees was not accounted for, because it was assumed that in the use phase that amount of $\mathrm{CO}_{2}$ would be lost as $\mathrm{CO}_{2}$ emissions, therefore being neutral to environmental impact. The distribution, packaging, retail, consumption and disposal stages were excluded as they were phases beyond the gate. The environmental impacts of field operations by human labor were not considered, as well as the transportation of human labor to the field, since they are considered additional environmental impacts for which one unique and univocally accepted accounting method has not been established yet [44].

The time boundary of the study was the complete lifetime of the orchard ( 25 years) including also young trees, i.e., from planting to the moment the trees are replaced. As pear cultivation is a perennial system presenting yield variability, it was considered more accurate to include the considerably low fruit yield during the first years of an established orchard (juvenile face). If only one productive year is considered, a significant underestimation of the environmental effects of the fruit production will occur [45].

\subsection{Life Cycle Inventory}

\subsubsection{Data Compilation/Data Quality}

Data compiled for the inventory phase emanated from real production data covering the first 3 years of the pear orchard (growth period) after planting and two consecutive years, 2011 and 2012, at the full production stage of the orchard. The low yield period of the orchard (4 years before reaching full production stage) as well as the rest of years which comprise the life span of the orchard were based on these real data. The low production period before the end-life of the current orchard was not considered, since it was arranged to replace the trees before they became unproductive due to senescence (year 2020). The end of life phase of the orchard was also excluded mainly for two reasons: 
firstly because it was not easy to predict the final destination of the orchard debris, ex situ disposed or recycled (the later may had having an environmental credit) [35]; secondly, due the low contribution to the overall environmental impact (0.03\%) [45].

Three different types of inventory data were used: foreground/primary data directly collected at the farm during field tests and surveys, background/secondary data retrieved from databases, from the literature or estimated using specific models and semi-specific data, based also on databases. The collected primary data refer to the consumption of the different inputs (e.g., diesel for the different field operations, fertilizers, plant protection products, machinery and tractors irrigation, and various transportation of agro-chemicals to the farm) (Table 1). The secondary data concerned all the information about the inputs during production stage from raw materials including fertilizer, agro-chemicals, machinery and infrastructure production. These data were taken from the Ecoinvent database, cut-off or recycled content system model version 3.1 [46]. The semi-specific data, mainly concerning pear cultivation processes and all the operations under specific conditions, were data coming from the Ecoinvent secondary database [46], adapted for the circumstances of the present study.

Table 1. Life cycle inventory-Inputs/Outputs.

\begin{tabular}{|c|c|c|c|}
\hline Pear Production & & Conventional & Variable Rate Application \\
\hline Inputs & First 3 Years & Year 2011 & Year 2012 \\
\hline \multicolumn{4}{|l|}{ Recourses } \\
\hline Precipitation $\left(\mathrm{m}^{3} / \mathrm{ha}\right)$ & 18,350 & 4050 & 6090 \\
\hline Land use (ha) & 1 & 1 & 1 \\
\hline \multicolumn{4}{|l|}{ Material/Processes } \\
\hline Tillage ploughing/diesel consumption (kg) & 25.06 & no & no \\
\hline Irrigation $\left(\mathrm{m}^{3}\right)$ & 4353 & 3870 & 2830 \\
\hline Fertiliser tractor use/diesel consumption (kg) & no & 29.74 & 11.65 \\
\hline \multicolumn{4}{|l|}{ Fertilisers } \\
\hline a. $\mathrm{N}(\mathrm{kg})$ all sources (manure, crop residues) & no & 251.42 & 126.58 \\
\hline b. $\mathrm{P}_{2} \mathrm{O}_{5}(\mathrm{~kg})$ & no & 100.86 & 11.24 \\
\hline c. $\mathrm{K}_{2} \mathrm{O}(\mathrm{kg})$ & no & 128.1 & 134.91 \\
\hline d. $\mathrm{H}_{3} \mathrm{BO}_{3}(\mathrm{~kg})$ & no & 0.826 & no \\
\hline e. $\mathrm{CaO}(\mathrm{kg})$ & no & no & 18.18 \\
\hline $\begin{array}{l}\text { Herbicides weed control/Mower tractor use/diesel } \\
\text { consumption }(\mathrm{kg})\end{array}$ & no & 91.52 & 93.17 \\
\hline Herbicide $(\mathrm{kg})$ & no & 10.66 & 10.66 \\
\hline Pesticide tractor use/diesel consumption (kg) & no & 137.38 & 151.42 \\
\hline Pesticides (kg) & 4.85 & 12.65 & 10.88 \\
\hline Thinning tractor use/diesel consumption (kg) & no & 24.42 & 24.86 \\
\hline Pruning tractor use/diesel consumption (kg) & no & 33.57 & 34.18 \\
\hline Harvesting tractor use/diesel consumption (kg) & no & 57.95 & 74.58 \\
\hline $\begin{array}{c}\text { Transportation/petrol }(\mathrm{kg}) \text { consumption (inputs/pear } \\
\text { transport to retail) }\end{array}$ & 0.89 & 24.58 & 24.74 \\
\hline Transportation (tkm) inputs to agriculture stores & 14.55 & 1979 & 1254 \\
\hline \multicolumn{4}{|l|}{ Outputs } \\
\hline Pear production $(\mathrm{t})$ & 0.909 & 18.81 & 28.11 \\
\hline Emission to air, water and soil & & & \\
\hline
\end{tabular}

The quantitative data of product output in the present study was defined as the pear yield in tons per one ha (Table 1), meaning the tons of pear fruits coming from three non-productive and the two productive years of the pear orchard. There were no co-products which meant no allocation of the calculated emissions or other means to deal with multi-functionality. In the secondary data used in the 
study, mainly economic allocation applied at the point where co-products leave the unit processes and wastes, residues and recycle products are handled using the cut-off concept [46]. The pruning debris of the trees were considered as part of the system, since they were gathered and left at the side of the field.

The attributional modelling approach was used for LCI. A methodology was adopted of modelling individual years and averaging over the orchards life time, rather than calculating the impact results for each year and then averaging. Since primary data were available for a few production years and yields were highly fluctuating due to alternate bearing, the involved farmers' and agronomists' experience/expert judgment was used to create the necessary data time series.

Data quality was evaluated based on the pedigree matrix developed by Weidema et al. (1998) [47]; the same method used to quantify data uncertainty in the Ecoinvent database. Uncertainty in the data sources was assessed according to five indicators: reliability, completeness, temporal correlation, geographic correlation, and technological correlation. Each indicator has been assigned a score between one and five (Table 2); one being the best and five the worst [47].

Table 2. Data quality evaluation based on the pedigree matrix for the years 2011 and 2012.

\begin{tabular}{cccccc}
\hline Flow & $\begin{array}{c}\text { Reliability of } \\
\text { Source }\end{array}$ & $\begin{array}{c}\text { Representativeness/ } \\
\text { Completeness }\end{array}$ & $\begin{array}{c}\text { Temporal } \\
\text { Correlation }\end{array}$ & $\begin{array}{c}\text { Geographical Further Technological } \\
\text { Correlation }\end{array}$ & 2 \\
\hline Correlation
\end{tabular}

\subsubsection{Emission Calculation/Outputs}

The emissions can be distinguished into direct and indirect emissions. Direct field and farm emissions are substances emitted from an agricultural area or directly at the farm. Indirect emissions denote emissions that occur in the upstream processes, such as purchased inputs used in agriculture or transportation. Direct emissions strongly depend on the site characteristics and are influenced by farm management practices. Indirect emissions are generally modelled with existing life cycle inventories, while specific models are generally used for direct emissions [48]. In Table 3 all the emissions calculated for the pear case study are presented.

Nitrogen emissions (nitrate leaching; ammonia volatilization, and nitrous and nitrogen oxides emissions in atmosphere), phosphate emissions in water and fossil $\mathrm{CO}_{2}$ to air were calculated with equations based on Intergovernmental Panel on Climate Change (IPCC) Guidelines (2006) [49] and Agroscope document $[50,51]$. Concerning the emissions to soil, pesticides were considered as the outputs to soil, since they were modelled as $100 \%$ of the active ingredient released into the soil [46]. Heavy metal emissions to soil were assumed insignificant to the relevant impact category (terrestrial ecotoxicity) compared to the other emissions (e.g., pesticides) according to the contribution analysis of the average pear GLO study of the Ecoinvent database [52]. 
Table 3. Life cycle inventory-Emissions.

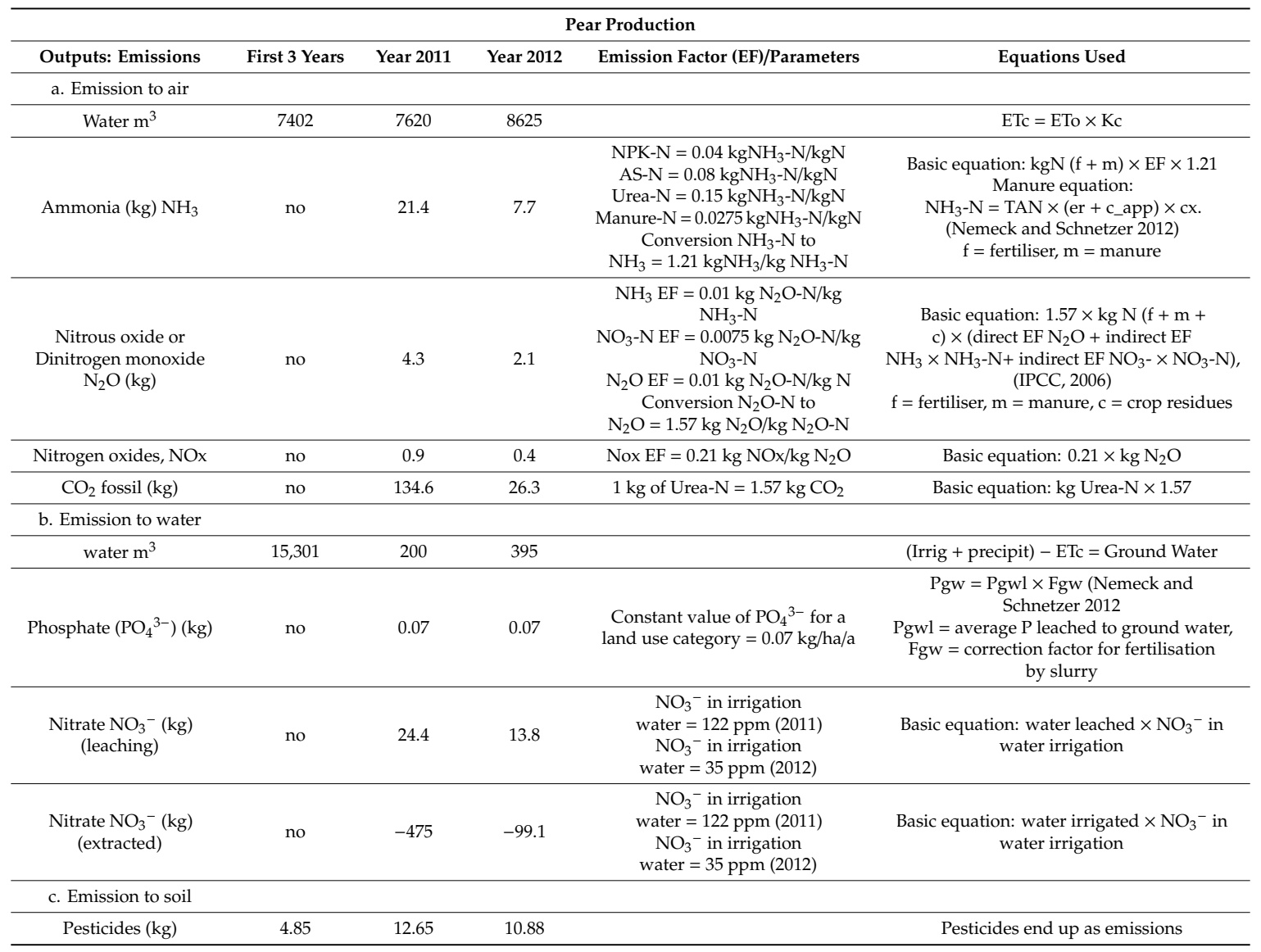

\subsubsection{Assumptions}

Before establishing the pear orchard, the land was occupied as arable, used for agriculture for a long time. Therefore, no impacts for land transformation were taken into account. The land transformation concerned 'Transformation from arable crop' to 'Transformation to permanent, crop, and fruit intensive' using a 1 ha unit. The cultivation system the farmer followed from planting until year 2011 was defined as conventional management, where $\mathrm{N}$ was applied uniformly. In the year 2012, a new $\mathrm{N}$ fertilization technique was applied, i.e., VRA where $\mathrm{N}$ replenishment was done site specifically according to $\mathrm{N}$ losses from the fruit yield of the previous year.

The main assumption made was that the analysis of the study included all the emissions and resource uses of the orchard's lifetime and all the production phases formatting the average of the pear orchard, rather than calculating the impact results for each year and then averaging. The three assumption scenarios for evaluating the robustness of the study results and conclusions were based on the physiological phenomena of alternate bearing which appeared in the specific pear orchard during its full productive period:

- Scenario 1: Fruit yield as 2011 uniform practice with alternate bearing; including pear orchard in the first three years + four years of low yield +9 years as 2011 uniform practice with low yield +10 years as 2011 uniform practice with high yield.

- Scenario 2: Fruit yield as 2012 VRA practice with alternate bearing; including pear orchard in the first three years + four years of low yield +9 years of low yield with 2012 VRA practice +10 years of high yield with 2012 VRA practice.

- Average Pear orchard with alternate bearing; including pear orchard in the first three years + four years of low yield +10 years of high and low yield alternatively as 2011 uniform practice +9 years of high and low yield alternatively with 2012 VRA practice. 


\subsubsection{Life Cycle Impact Assessment}

Endpoint/Midpoint Methods

LCIA "is aimed at understanding and evaluating the magnitude and significance of the potential environmental impacts of a product system" according to ISO 14040 (2006) [39]. Impacts can be quantified at different stages in the cause-effect chain. An endpoint method looks at the environmental impact at the end of a cause-effect chain. A midpoint method looks at the impact earlier along the cause-effect chain. Midpoints are used for a more specific and detailed analysis, whereas endpoints are useful to communicate the results obtained to a broader audience. A number of methods used by LCIA, convert the emissions of hazardous substances and extractions of natural resources into impact category indicators at the midpoint level (such as acidification, climate change and ecotoxicity), while others employ impact category indicators at the endpoint level (such as damage to human health and damage to ecosystem quality). The existence of methods addressing midpoints and others addressing endpoints can be justified and is legitimate given that the choice of method is intricately linked to the product/activity under assessment. Typically, for an ISO compatible study, the results are presented at the midpoint level.

The results are presented in the obligatory step (according to ISO standards) of the characterization phase initially, where the environmental interventions are quantified in terms of a common unit for each midpoint and endpoint category, revealing the contribution of each process to the total environmental impact. The optional steps of normalization and weighting are also presented. The aim of the normalization is to understand better the relative magnitude of the different impacts, by dividing them with a common reference value [40]. Normalization reveals which environmental impacts are large or small without giving any information about their relevance to each other. The normalized LCIA results should not be summed directly since the severity of the different impact categories has not yet been accounted for. The weighting step is also optional in LCIA according to the ISO standards and at the same time is the most disputable step [40]. It reveals the relative importance among the impact categories under study in a quite arbitrary sense. Weighting involves assigning distinct quantitative weights to all impact categories expressing their relative importance. If needed for the interpretation, and if it is in accordance with the goal of the LCI/LCA study, a weighting of the normalized indicator results may be performed.

Additionally, a Monte Carlo analysis was used to evaluate the uncertainties of the LCIA results. An uncertainty analysis is a procedure to determine how uncertainties in data and assumptions progress in the calculations and how they affect the reliability of the LCIA results. Moreover, a sensitivity analysis was performed to determine how changes in data and methodological choices affect the results of the LCIA.

\section{Recipe}

The ReCiPe 2008 midpoint (hierarchist) method [53] adapted to include a water scarcity indicator [54] was used as the default method in this study. IMPACT $2002+$ midpoint was also used as the second method to verify the robustness of the results. All three methods also have the option to explore the results at the endpoint. This analysis was added to the interpretation of the results for the selection of relevant impact categories. The results of a product LCA with an endpoint method can show the relative contribution of the "midpoint categories" to human health, ecosystems and resources. Categories that have insignificant contribution to these endpoint categories are left out of the results at midpoint.

A comparison of the characterization results of the Impact assessment between the current pear study (pear Greece) and the pear global average production (Pear GLO) is also performed using ReCiPe methodology. 


\section{Results}

All the results originated from the characterization step of the Impact Assessment, where the environmental interventions were quantified in terms of a common unit for each midpoint and endpoint category. The endpoint results were used to determine which midpoint categories had a significant contribution to the endpoints. Afterwards, at the end of the section we refer to normalization and weighting steps to evaluate the relative importance across all the midpoint categories to a single score indicator of the product system under study. It must be noted that the weighing step involves a value choice, where in the normalized indicator results each impact category is multiplied by numerical factors according to their relative importance and aggregated in a single score.

\subsection{Endpoint Results}

\section{ReCiPe Method Results in Characterization Phase}

Endpoint calculation determined the most important impact categories for the study by selecting those categories which contributed more that $1 \%$ of the total contribution per endpoint category for the present pear study to the environmental impacts (Table 4). Only eight impact categories remained in the endpoint level of the ReCiPe method: Climate change, Human toxicity, Particulate matter formation, Terrestrial ecotoxicity, Agricultural land occupation, Metal depletion, Fossil fuel depletion, Water scarcity.

Table 4. Impact assessment results using ReCiPe 1.11 + Pfister et al. (2011) endpoint method.

\begin{tabular}{cccc}
\hline Impact Category & Unit Per Kg of Pears & Total & Importance \\
\hline Climate change Human Health & DALY * & $4.00 \times 10^{-7}$ & $61 \%$ \\
Ozone depletion & DALY & $8.75 \times 10^{-11}$ & $0 \%$ \\
Human toxicity & DALY & $1.95 \times 10^{-8}$ & $3 \%$ \\
Photochemical oxidant formation & DALY & $6.21 \times 10^{-11}$ & $0 \%$ \\
Particulate matter formation & DALY & $2.31 \times 10^{-7}$ & $35 \%$ \\
Ionising radiation & DALY & $1.81 \times 10^{-10}$ & $0 \%$ \\
Water scarcity HH & DALY & $4.06 \times 10^{-9}$ & $<1 \%$ \\
Sub-Total & DALY & $6.55 \times 10^{-7}$ & $100 \%$ \\
Climate change Ecosystems & species.yr & $2.26 \times 10^{-9}$ & $21 \%$ \\
Terrestrial acidification & species.yr & $1.88 \times 10^{-11}$ & $0 \%$ \\
Freshwater eutrophication & species.yr & $1.41 \times 10^{-12}$ & $0 \%$ \\
Terrestrial ecotoxicity & species.yr & $3.48 \times 10^{-10}$ & $3 \%$ \\
Freshwater ecotoxicity & species.yr & $1.12 \times 10^{-12}$ & $0 \%$ \\
Marine ecotoxicity & species.yr & $6.71 \times 10^{-14}$ & $0 \%$ \\
Agricultural land occupation & species.yr & $7.69 \times 10^{-9}$ & $71 \%$ \\
Urban land occupation & species.yr & $1.2 \times 10^{-10}$ & $<1 \%$ \\
Natural land transformation & species.yr & $8.50 \times 10^{-11}$ & $<1 \%$ \\
Water scarcity EQ & species.yr & $3.51 \times 10^{-10}$ & $3 \%$ \\
Sub-Total & species.yr & $1.09 \times 10^{-8}$ & $100 \%$ \\
Metal depletion & USD & $2.51 \times 10^{-3}$ & $8 \%$ \\
Fossil depletion & USD & $1.28 \times 10^{-2}$ & $38 \%$ \\
Water scarcity R & USD & $1.79 \times 10^{-2}$ & $54 \%$ \\
Sub-Total & USD & $3.32 \times 10^{-2}$ & $100 \%$ \\
\hline & Adusta & & \\
\hline & & &
\end{tabular}

${ }^{*}$ DALY:Disability Adjusted Life Years.

\subsection{Midpoint Results}

Midpoint calculations determined the most important impact categories of the Impact assessment using the ReCiPe midpoint method, presented in Table 5 and Figure 3. 
Table 5. Impact assessment results using ReCiPe midpoint $1.11+$ Pfister et al. (2011) water method.

\begin{tabular}{ccc}
\hline Impact Category & Unit Per Kg of Pears & Total \\
\hline Climate change & $\mathrm{kg} \mathrm{CO}$ eq & 0.285 \\
\hline Human toxicity & $\mathrm{kg} \mathrm{1.4-DB} \mathrm{eq}$ & 0.028 \\
\hline Particulate matter formation & $\mathrm{kg} \mathrm{PM10} \mathrm{eq}$ & 0.001 \\
\hline Terrestrial ecotoxicity & $\mathrm{kg} \mathrm{1.4-DB} \mathrm{eq}$ & 0.002 \\
\hline Agricultural land occupation & $\mathrm{m}^{2} \mathrm{a}$ & 0.478 \\
\hline Water depletion & $\mathrm{m}^{3}$ & 0.085 \\
\hline Metal depletion & $\mathrm{kg} \mathrm{Fe} \mathrm{eq}$ & 0.035 \\
\hline Fossil depletion & $\mathrm{kg} \mathrm{oil} \mathrm{eq}$ & 0.077 \\
\hline
\end{tabular}

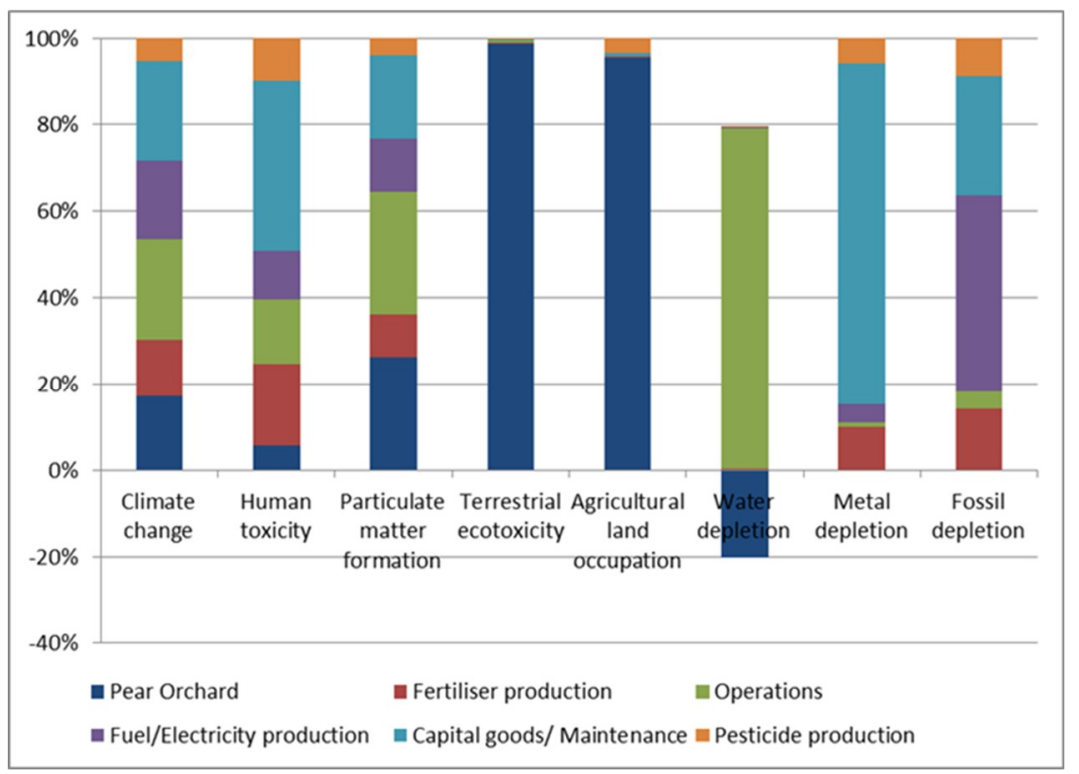

Figure 3. Processes contribution of $1 \mathrm{~kg}$ average pear to the most significant impact categories (using average data with alternate bearing of all the emissions and resource uses of the orchard's lifetime and all the production phases).

The practices and materials used for completing the inventory, were grouped in the impact assessment phase in groups representative of the data included. In the present pear study, the groups were: (1) Pear orchard, including all the agricultural practices applied during pear production; (2) Fertilizer production; (3) Operations, mainly considering the energy consumption (fuels and electricity); (4) Energy/Fuel production; (5) Capital goods/Maintenance; and (6) Pesticide production.

The pear production system (Pear Orchard group) was almost exclusively responsible for the emissions to the Terrestrial ecotoxicity and Agricultural land occupation impact categories. The Terrestrial ecotoxicity category concerned emissions to the soil, including the emissions coming from pesticides, while the impacts of the Agricultural land occupation category were due to land use for a specific period of time. The average fruit yield (20.3 $t / h a)$ for the whole life span of the pear orchard was smaller compared to the global average pear production [55]. Thus, land occupation was found to be 0.05 ha $\times$ year/ton of pears, justifying a high impact of Agricultural land occupation in the current pear study. Additionally, the Pear Orchard Group covered a substantial part of the Particulate matter formation due to $\mathrm{NOx}$ and $\mathrm{NH}_{3}$ and of Climate Change due to $\mathrm{N}_{2} \mathrm{O}$ and $\mathrm{CO}_{2}$. These air emissions were all produced from the use of fertilizer inputs in the orchard. Finally, in water depletion the negative percentage represents the water irrigation pumped from the ground for the pear fruit yield. The operations group showed a significant contribution to the Water Depletion impact category 
and consequently in Particulate matter formation and Climate Change. Concerning the background processes, the agricultural machinery production and maintenance of all the equipment and machinery used, had an important contribution to the majority of the impact categories.

Analyzing further each impact category to reveal the main contributors, it was revealed that for the Climate change and Particulate matter formation impact categories (depicting the use of fertilizers) the $\mathrm{CO}_{2}$ fossil and $\mathrm{N}_{2} \mathrm{O}$ to air contributed more than $95 \%$ of the total emissions in the Climate Change category, while $55 \%$ of the total emissions for the Particulate matter formation was due to the NOx and $\mathrm{NH}_{3}$ emissions to the air (Tables A4 and A5, Appendix A). In the Human toxicity impact category, arsenic, lead and mercury emissions to air contributed almost 50\%, (Table A6, Appendix A), where in Terrestrial ecotoxicity among a variety of pesticides only three substances, Chlorpyrifos, Dithianone and Phosmet had more than $80 \%$ of the total emissions in the impact category. Finally, in the Fossil depletion impact category the oil (crude substance) representing the diesel consumption, was responsible for more than $50 \%$ of the total emissions of the category.

\subsection{Normalization}

The relative contribution to the impacts from the production of $1 \mathrm{~kg}$ of average pear with alternate bearing (using the Endpoint ReCiPe plus Pfister method), generated by a world inhabitant in 2000 (the reference value) is shown in Figure 4 and Table A1 (Appendix A) (all resources consumed and emissions released in the World during 2000; the World was chosen as the reference, because using Europe as a reference only includes emissions and resource use inside Europe, thus excluding imports and exports). The endpoint method was chosen to depict the normalization results. The unit of the normalization results is person year per $\mathrm{kg}$ of pears.

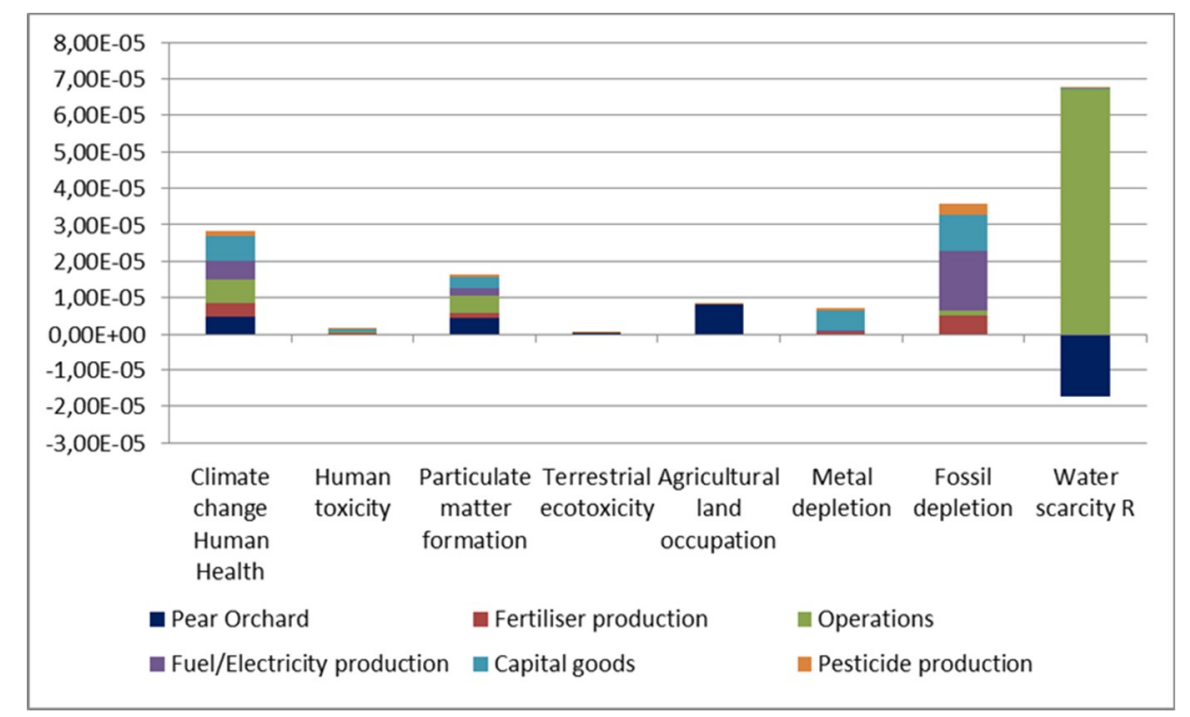

Figure 4. Contribution of $1 \mathrm{~kg}$ average pears to the most important impact categories, according to normalization step of the pear study.

The magnitude of the most important impact categories was based on the characterization results. Irrigation process and specifically the use of electricity affected the environmental impact more. It should also be noted that normalization values concerned the year 2000, while the data from the pear study are more recent.

\subsection{Weighting}

The endpoint method was chosen to depict the weighted results. The unit of the weighted results was the dimensionless Pt. The most important impact categories for the study were determined by selecting those categories which contributed more than $1 \%$ of the total contribution to the environmental 
impacts per endpoint category. The Terrestrial ecotoxicity category was not relevant any more in the weighting step (Table A2, Appendix A). This is due to the normalization reference used in the study, meaning that the normalization reference, resulted from the World reference of the year 2000, was higher for the ecosystem and lower for the toxicity (Terrestrial and Human). In Figure 5 the aggregated weighting results into a single score is presented, considering only the most relevant impact categories. The remaining categories were less than $1 \%$ and were not shown in the graph.

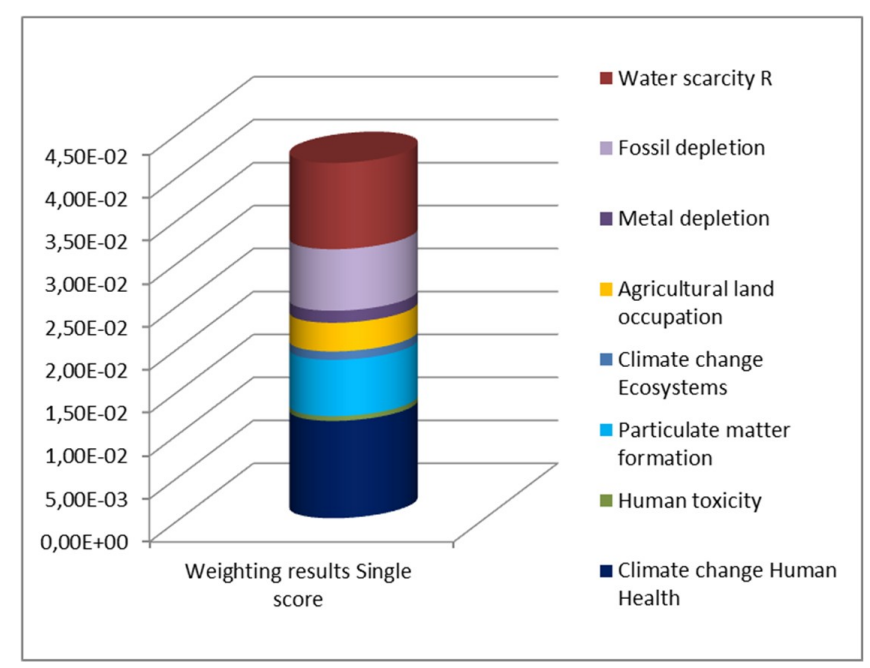

Figure 5. Contribution of $1 \mathrm{~kg}$ of average pear to the most important impact categories (1\% cut-off) according to weighting step of the pear study.

Interpreting Figure 5, Climate change, Water scarcity, Fossil fuels and Particulate matter formation are the most contributing impact categories to the overall environmental impact of the whole life span of the pear orchard under study, followed by Agricultural land occupation, Metal depletion and Human toxicity.

\subsection{Uncertainty}

The Monte Carlo analysis (Table A3, Appendix A) performed revealed that the uncertainty was low for most impact categories except for water depletion. The high uncertainty in the water depletion category was probably due to water flows from the ground water which were characterized with factors higher than one (1) and that water flows to surface water were characterized by factors lower than one (1), which creates an increased amount of calculated uncertainty in the Monte Carlo analysis, while in reality the 'from and to' flows are related. The low uncertainty in the human toxicity category was caused by a waste treatment process in Ecoinvent that is associated with a coal mining process for producing electricity. The electricity was subsequently used for producing the different inputs for the pear orchard. The emissions of metals and other toxic substances in the waste treatment process had such extremely high uncertainty factors that they affected the results for the pears. As was mentioned earlier, the toxic substances most responsible for the emissions in the impact category of Human toxicity were arsenic, lead and mercury.

\subsection{Sensitivity}

Sensitivity analysis included the comparison of the three scenarios, where all scenarios were based on primary data of the 3 first non-productive years of the orchard and the years 2011 (uniform practice) and 2012 (VRA practice). The Average Pear fruit yield represented the lifespan of the pear orchard, comprising years of $\mathrm{N}$ uniform application and N VRA under alternate bearing, while Scenario 1 represented the lifespan of the orchard when only uniform $\mathrm{N}$ was applied under alternate bearing and Scenario 2 when only N VRA was performed under alternate bearing. Compared to the Average 
pear fruit yield, Scenario 2 presents reduced emissions per impact category except Agricultural land occupation, while Scenario 1 presents increased emissions in all the important impact categories of the study, except for Agricultural land occupation (Figure 6).

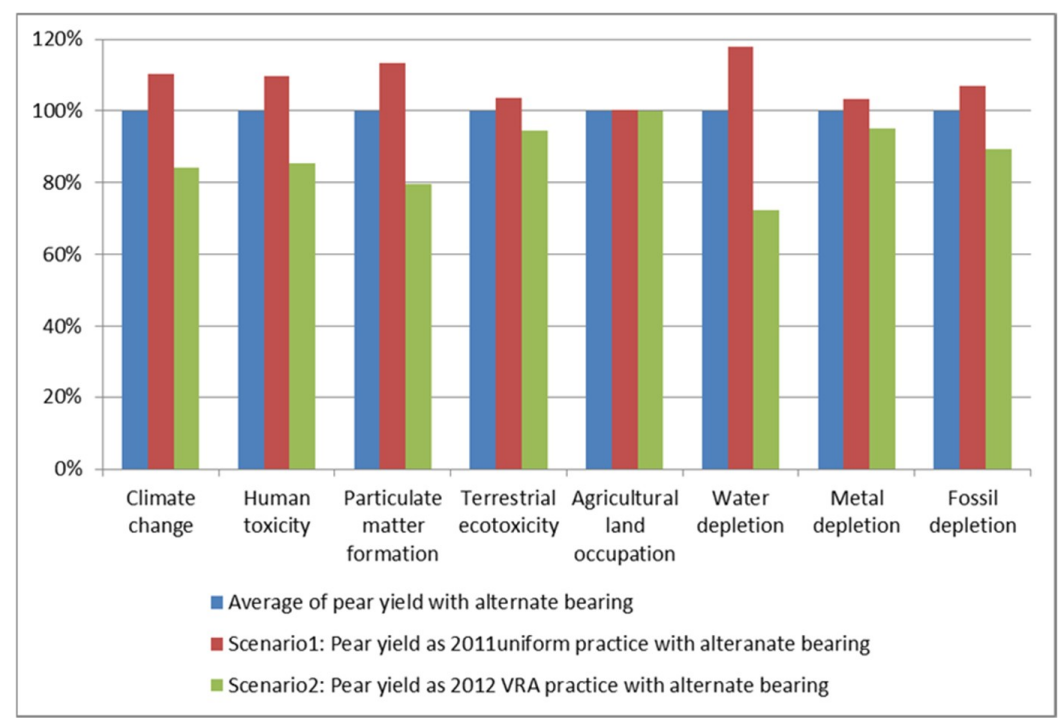

Figure 6. Comparison of the average pear production with the two scenarios.

Both studied years, 2011 and 2012, had the same agricultural practices, except for the application of basic $\mathrm{N}$ fertilization in the year 2012. Furthermore, they presented different fruit yields: the 2011 yield of 18.81 tons per hectare and the 2012 yield of 28.1 tons per hectare. Thus, the two competing aspects which determined the differences in the environmental profiles of the pear orchard in the years 2011 and year 2012 were: (a) the basic fertilizer application of the year 2012, where not only the amount of $\mathrm{N}$ fertilizer was reduced, but also the VRA technique of $\mathrm{N}$ application was used, and (b) the difference in the yield achieved per ha. Fruit yield is an important factor defining which impact categories have greater contribution in the total environmental impact. In the current study, this factor was combined with a reduced $\mathrm{N}$ fertilization amount in the year 2012 as a result of the VRA technique (Figure 7). As a consequence of this combination (increased yield with reduced $\mathrm{N}$ ), there was a reduction of the important emissions to air coming from the fertilization agricultural practice as Figure 8 shows.

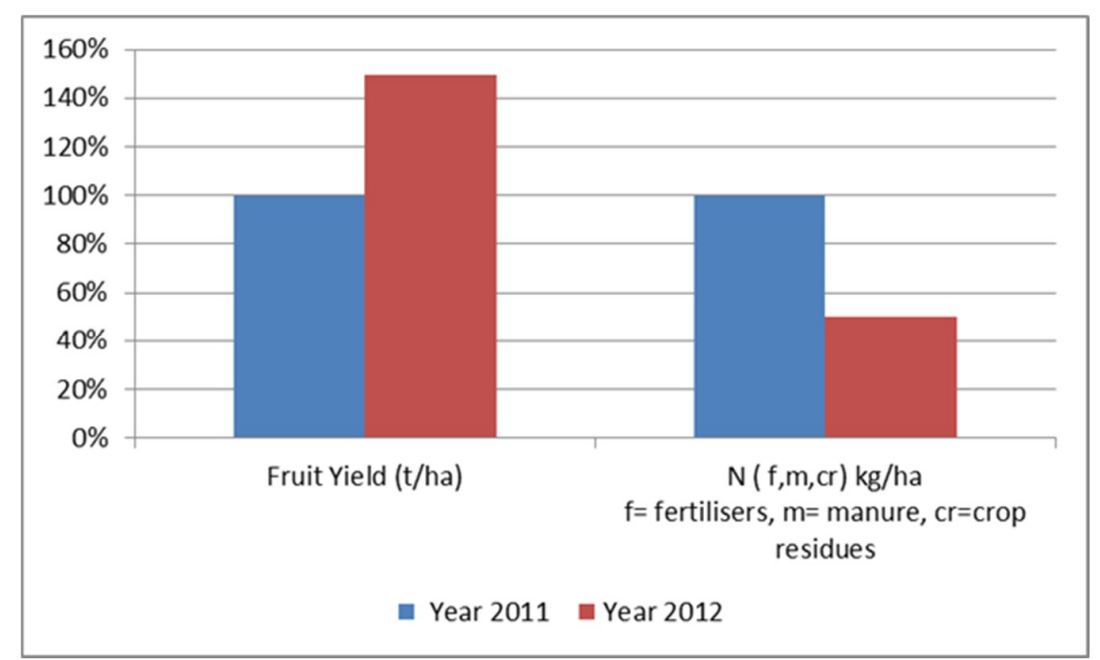

Figure 7. Comparison of the fruit production years 2011 and 2012 in yield (t/ha) and N application (kg/ha). 


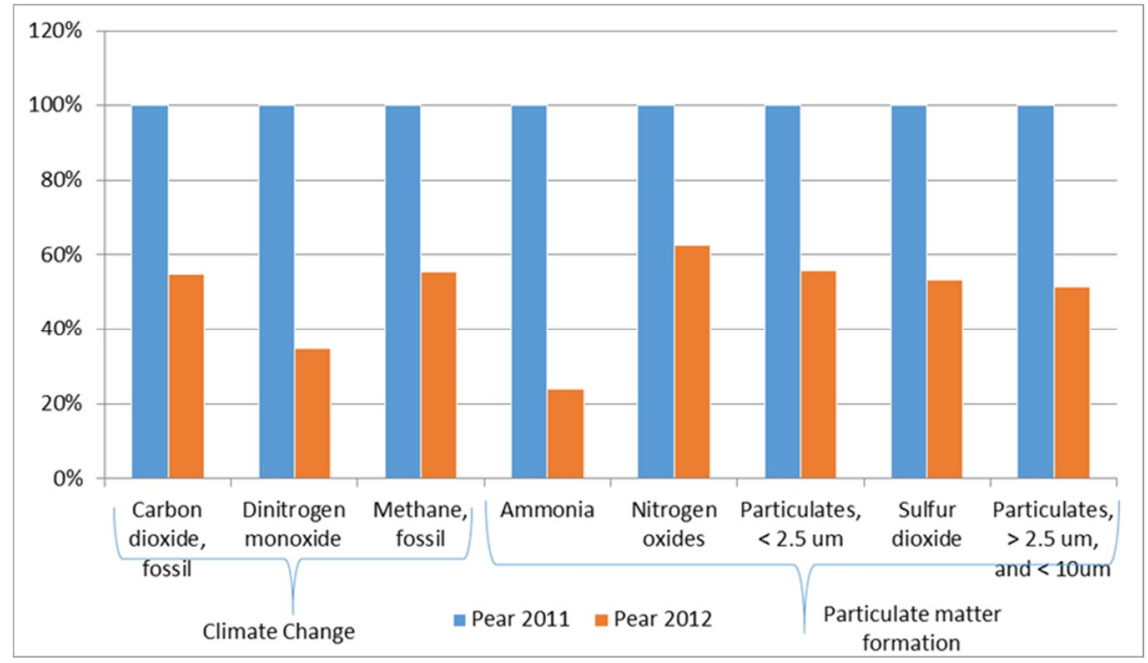

Figure 8. Air emissions (per kg of pear) in Climate change and Particulate matter formation impact categories coming from the fertilizer application in the field the years 2011 and 2012.

In the case of the reduced fruit yield in 2012 (VRA), regardless of the fact that N VRA was used, there was an increase of $49 \%$ in all the impact categories compared to the 2012 VRA practice (Figure 9). In case of the 2011 uniform practice having increased yield, it seemed that the emissions in the highest impact categories were increased without reaching the previous condition (Figure 9). Finally, when the 2011 uniform practice had low yield almost all the impact categories increased substantially compared to other cases. Thus, first the yield production and secondly the fertilization practice had a decisive role concerning the environmental impacts of the present pear study. If they are combined, the desired outcome is depicted in the case of the 2012 VRA practice as depicted in Figure 9 or considering the whole life span of the orchard, in Scenario 2 (Figure 6). It is clear, therefore, that N VRA had a positive environmental result provided that yield does not adversely affect it at least to considerable extent.

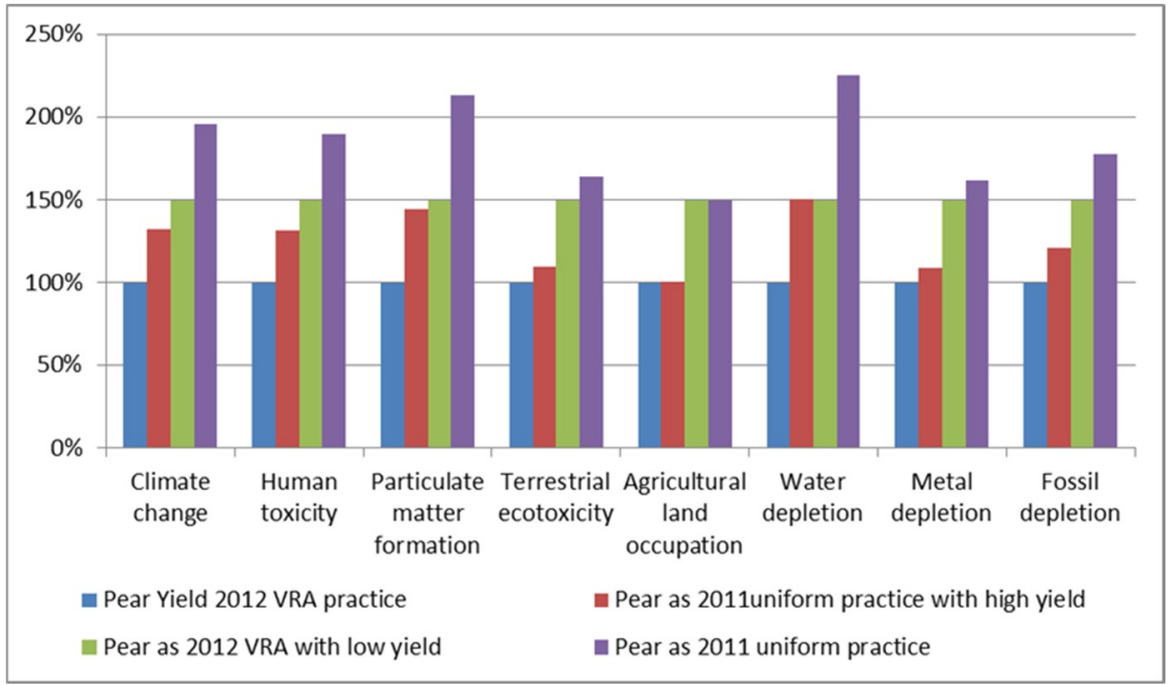

Figure 9. Yield comparisons, $1 \mathrm{~kg}$ of pears, of the 2011 uniform practice and 2012 variable rate application (VRA) practice with alternate bearing (high and low yield).

As was mentioned earlier, the yield pattern over a four-year observation of the studied pear orchard suggested a limited alternate bearing behavior for Coscia pear cultivar. Alternate bearing causes an unstable yield, where a year of high yield is followed by a year of low yield due to inherent plant factors including the availability of carbohydrates and possibly $\mathrm{N}$ [56]. In this case, provided 
that it is verified in data from more years, it would be better to apply high $\mathrm{N}$ rates in the low yielding sites of the previous year (and high yielding in the present year) with the VRA technique to sustain the high requirements of present season's crop and secure the floral bud formation for next year's yield. This approach could possibly mitigate alternate bearing by supplying the necessary $\mathrm{N}$ for adequate vegetative growth and flower bud formation for next season's crop. It should be clear that the VRA technique applied in the present study was based on the opposite approach: wherever the yield was high, the amount of $\mathrm{N}$ fertilization was also high, and wherever the yield was low, $\mathrm{N}$ fertilization was low in order to handle field variation based on outputs. In Figure 10 the differences among the average pear scenario of $1 \mathrm{~kg}$ of pears and the single fruit crop in years 2011 and 2012 is shown. The average pear yield with alternate bearing has a large difference from the studied years: pear 2011 uniform practice with low yield and pear 2012 VRA practice with high yield. On the contrary it is shown that this difference is limited, when the fruit yields are switched (pear yield 2011 uniform practice with high yield and pear yield 2012 VRA practice with low yield), since increased environmental impact induced by the 2011 uniform practice (increased uniform $\mathrm{N}$ application) is ameliorated with high yield and simultaneously in the 2012 VRA practice good environmental performance is deteriorated by low yield.

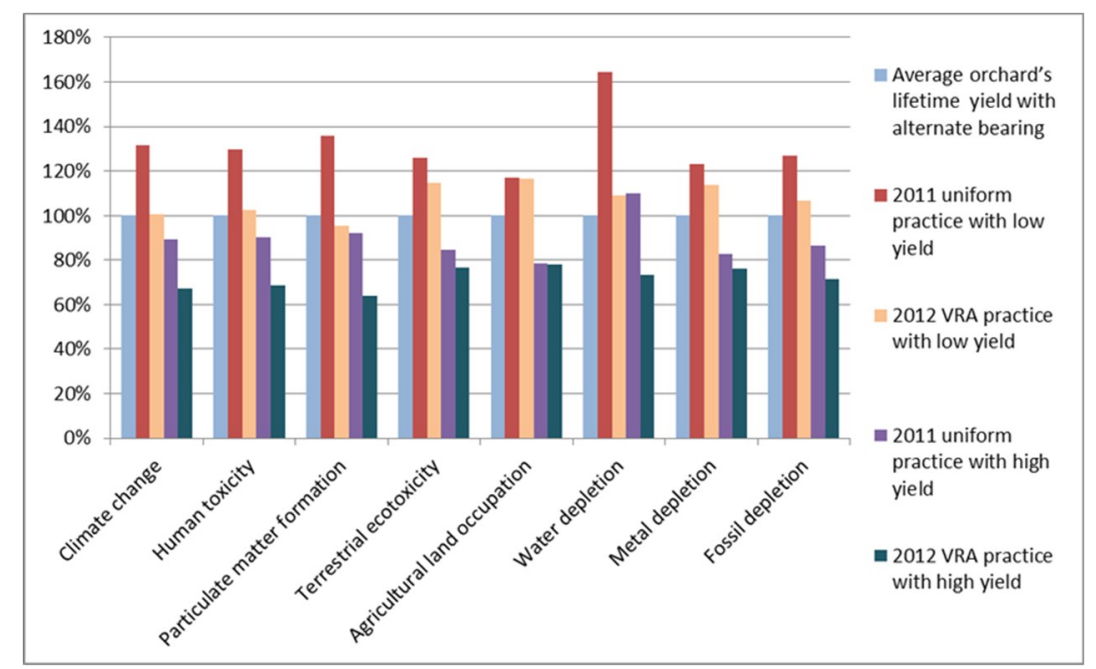

Figure 10. Yield comparisons of $1 \mathrm{~kg}$ of average pear production and the single year 2011 uniform practice and 2012 VRA practice with alternate bearing (high and low yield).

A comparison of the characterization results of the Impact assessment between the current pear study (Pear Greece) and the pear global average production (Pear GLO) is presented in Figure 11. The pear average global production data was taken from the Ecoinvent data base, which also was based on the results of research by Stoessel et al. (2012) [55] concerning LCI, carbon and water footprint of fruits and vegetables. (The table showing the results of the comparison is presented in the Table A7 of Appendix A).

The results between the two pear studies seemed to be similar in Fossil depletion, Human toxicity, Particulate matter formation and the Climate change category, even though the pear yield in Greece was lower. Agricultural land occupation was higher in the pear Greece production for the same reason. In the Terrestrial ecotoxicity impact category, the pesticides were considered direct, having a major contribution to this category, as well as water depletion being higher for Greece compared to the global average. 


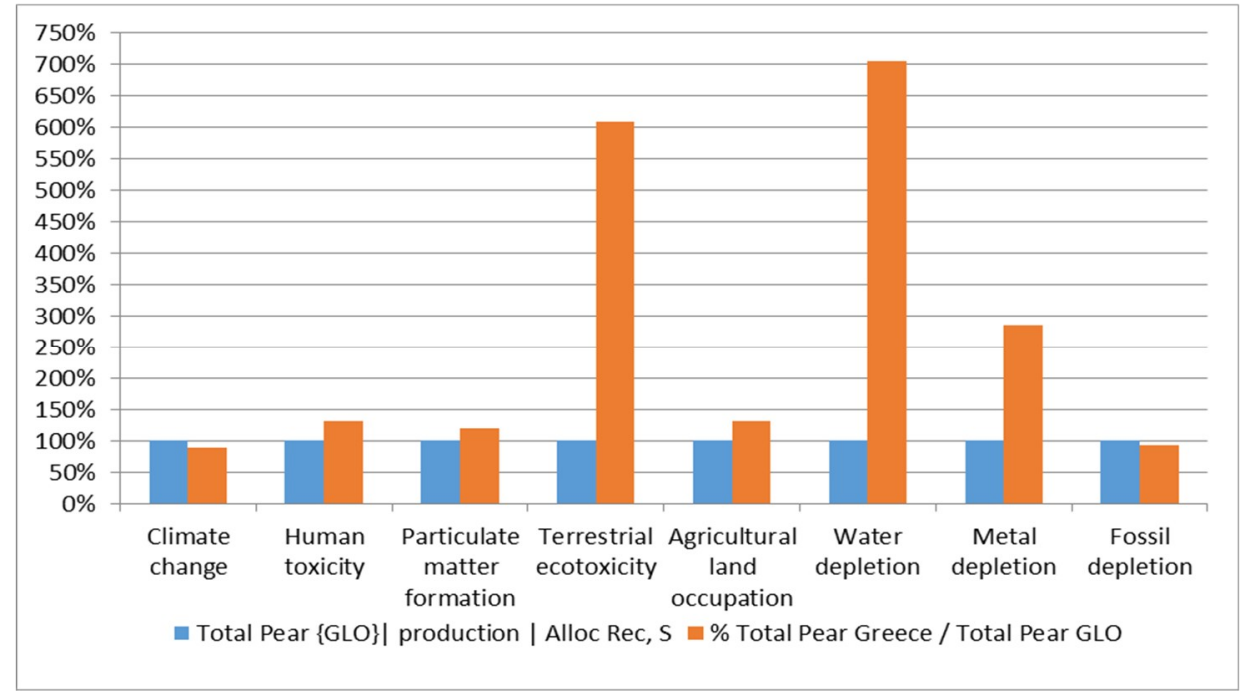

Figure 11. Comparison of pear production for the Greece (GR) and global (GLO) average.

\section{Discussion/Interpretation}

A large amount of site specific data was collected for all the agricultural practices used in the studied orchard during three first non-productive and two consecutive productive years adopting different $\mathrm{N}$ fertilizer application systems, uniform and VRA, and the most important emissions from the orchard $\left(\mathrm{N}_{2} \mathrm{O}, \mathrm{NOx}, \mathrm{NH}_{3}, \mathrm{CO}_{2}\right)$ were calculated based on the available data according to the most recent scientific insights for conducting agricultural LCAs. A methodology was adopted for modelling individual years and averaging over the orchard's lifetime, rather than calculating the impact results for each year and then averaging. Potential limitations to the current study could be the data compilation which is restricted to the growing period of trees after planting (3 first years: 1995, 1996 and 1997) and in two years in the full production phase of the orchard, 2011 and 2012. An orchard's life span usually lasts for a period of 20 years after planting. This pear orchard's life span started in 1995 and will be completed in 2020. Furthermore, the complex system of the present pear cultivar of possible alternate bearing yields (high one year and low the next) also needs more years of data to depict the reality of the life span of the orchard. Future research will need to take into account this possibility and test the validity of our assumptions.

In contribution analysis of the characterization phase of the Impact Assessment it was found that irrigation due to groundwater pumping, machinery production and pear fruit production in the year 2011 contributed most to the environmental impacts of this pear study (Figure A1 in Appendix A presents the most contributing processes of the current study). These results agree with LCA studies in peaches by Ingrao et al. (2015) [36], and Vinyes et al. (2015) [37], where irrigation, land use and fertilizer and pesticide production also contributed most to the environmental impacts. The most contributing impact categories to the total environmental impact were almost the same in the characterization and weighing steps of the Impact assessment, with the exception of the Terrestrial ecotoxicity impact category. The aggregation of the weighted results into a single score showed that Climate change, Water scarcity, Fossil fuels and Particulate matter formation had higher values than Agricultural land occupation, Metal depletion and Human toxicity. In the characterization step on the other hand, it was distinguished which impact categories were the most important within the endpoint category (or damage category), without showing the relative importance among the impact categories affecting different damage categories. When the characterization results of the Impact assessment between the current pear study (pear Greece) and the pear global average production (Pear GLO) were compared (Figure 11 and Table A7 of Appendix A), all impact categories were similar except the Terrestrial ecotoxicity impact category and Water depletion. In Greece, the data concerning pesticide use in pear production were primary data that correspond to a preventive protection programme of a local 
agronomic station. This is interpreted either as the Greek program having used more pesticides than the global pear production or having used higher doses of the chemicals. Moreover, in the global production case, more precise prediction weather models for calculating the amounts of the pesticides might be used which probably minimized the total amounts of chemical use. Finally, water depletion in Greece seemed to be much higher, without implying that this pear orchard was inefficiently irrigated. The high values in water depletion may be stemmed from excessive use of water due to the irrigation schedule of the specific area. Furthermore, the pear orchard was established in a temperate region with a humid-arid climatic condition, which explained the water depletion impact results. On the other hand, the water consumption in the Ecoinvent dataset was based on a rough global average, which may not completely represent the real average situation of pears in each region.

In the present study, two different systems of $\mathrm{N}$ fertilization were compared, uniform application and VRA. Both studied years, 2011 and 2012, had the same agricultural practices except for the system adopted for $\mathrm{N}$ fertilization the year 2012 and the yield, where using the VRA half amount of $\mathrm{N}$ resulted in double yield in the year 2012. The comparison of the two practices revealed the environmental benefit of using the VRA technique, since it resulted in an almost $50 \%$ reduction of air emissions from fertilizer application. When the three scenarios (Figure 6) were compared under the alternate bearing condition of the pear orchard over the whole lifespan of the orchard (average pear yield, pear yield as 2011 practice and pear yield as 2012 practice), the VRA technique revealed a better environmental performance, a conclusion also supported by the average pear contribution analysis of the processes (Appendix A Figure A1), which showed that pear production in the year 2012 had reduced an overall environmental impact compared to year 2011. This conclusion enhanced the importance of the 2012 agricultural practice; that is that VRA of $\mathrm{N}$ fertilizer had better environmental performance in both of alternate bearing of 2012 practices (high and low yield), since the contribution was lower than the production year of 2011 practices for both cases of yield (high and low). Thus, it was considered that the nitrogen related emissions from the field significantly affected part of the pear's life cycle impact. Generally, limiting the use of agro-chemicals, diesel and water through PA management and VRA technique is important for reducing the environmental footprint of pears. However, increasing the yield also had a large effect on the impact scores. It is important, therefore, to assure that VRA secures a similar yield for the orchards as was proven for the limited years of the present study. Variable rate fertilization was combined with the high yield of 2012 and resulted in low environmental impacts. The variable rate strategy could be applied not only in fertilization practice, but also in irrigation and pesticide applications. VRA of inputs can lead to the lowest environmental footprint, whilst maintaining crop yield. Thus, any recommendation for improving the agricultural management system will include maximizing the yield/input ratio, first by applying VRA in all inputs and especially to irrigation, which contributed most to the total environmental impacts. Furthermore, pesticide VRA with more targeted applications and carefully selected plant protection products with regard to toxicity characterization factors, could also result in the reduction of the environmental impacts, if it does not negatively influence the productivity per hectare.

\section{Conclusions}

The objective of this case study was to develop the environmental profile of the particular pear orchard under different agricultural practices, comparing the environmental impacts of using different $\mathrm{N}$ fertilizer application techniques. The main conclusions which emerged from this LCA study are summed up below:

- The LCA analysis of the pear orchard study revealed that although $\mathrm{N}$ fertilizer is not dominating, it is still important in the overall environmental impact. High fruit yield was combined with reduced a $\mathrm{N}$ fertilization amount, using VRA technique, resulting in the reduction of the important emissions to air coming from the fertilization agricultural practice. 
- The irrigation process and specifically the use of electricity affected the environmental impact of the pear study more. Machinery production and pear fruit production in the year 2011 significantly contributed to the environmental impacts of this pear study.

- Maximizing the yield/input ratio, by applying VRA in all impactful inputs like irrigation will improve the environmental profile of the pear orchard. The VRA technique could be used for pesticide application, if it does not negatively affect the productivity per hectare

- $\quad \mathrm{N}$ VRA is a practice that can offer considerable reduction of environmental impact when it is combined with high yield. In a low yield year, the VRA technique still presents better environmental behavior compared to uniform application.

- $\quad \mathrm{N}$ VRA is a practice that can offer considerable reduction of environmental impacts and should be recommended to farmers as an environmental precision management practice.

Author Contributions: All authors contributed to the present paper; A.V. performed the field experiments and V.L. contributed to collection of primary data of the pear orchard; A.V. and S.F. analyzed the data; T.G., S.F. and G.N. and N.K. contributed with their experience in the analysis and presentation of data; A.V. performed the LCA. All authors have read and agreed to the published version of the manuscript.

Funding: This research received no external funding.

Conflicts of Interest: The authors declare no conflict of interest.

\section{Appendix A}

Table A1. Normalization results using ReCiPe endpoint 1.11 + Pfister et al. (2011) water method.

\begin{tabular}{|c|c|}
\hline Impact Category & Normalization \\
\hline Climate change Human Health & $2.83 \times 10^{-5}$ \\
\hline Ozone depletion & $6.21 \times 10^{-9}$ \\
\hline Human toxicity & $1.39 \times 10^{-6}$ \\
\hline Photochemical oxidant formation & $4.40 \times 10^{-9}$ \\
\hline Particulate matter formation & $1.64 \times 10^{-5}$ \\
\hline Ionising radiation & $1.28 \times 10^{-8}$ \\
\hline Water scarcity HH & $2.88 \times 10^{-7}$ \\
\hline \multicolumn{2}{|l|}{ Sub-Total } \\
\hline Climate change Ecosystems & $2.45 \times 10^{-6}$ \\
\hline Terrestrial acidification & $2.04 \times 10^{-8}$ \\
\hline Freshwater eutrophication & $1.52 \times 10^{-9}$ \\
\hline Terrestrial ecotoxicity & $3.78 \times 10^{-7}$ \\
\hline Freshwater ecotoxicity & $1.21 \times 10^{-9}$ \\
\hline Marine ecotoxicity & $7.28 \times 10^{-11}$ \\
\hline Agricultural land occupation & $8.34 \times 10^{-6}$ \\
\hline Urban land occupation & $1.30 \times 10^{-7}$ \\
\hline Natural land transformation & $9.21 \times 10^{-8}$ \\
\hline Water scarcity EQ & $3.81 \times 10^{-7}$ \\
\hline \multicolumn{2}{|l|}{ Sub-Total } \\
\hline Metal depletion & $7.02 \times 10^{-6}$ \\
\hline Fossil depletion & $3.58 \times 10^{-5}$ \\
\hline Water scarcity $\mathrm{R}$ & $2.88 \times 10^{-7}$ \\
\hline Sub-Total & \\
\hline
\end{tabular}


Table A2. Characterization and Weighted results using ReCiPe endpoint $1.11+$ Pfister et al. (2011) water method.

\begin{tabular}{|c|c|c|c|c|c|c|c|}
\hline Impact Category & $\begin{array}{l}\text { Unit per kg } \\
\text { of Pears }\end{array}$ & $\begin{array}{c}\text { Characterisation } \\
\text { Results }\end{array}$ & Importance \% & $\begin{array}{c}\text { Weighted } \\
\text { Results Single } \\
\text { Score (Pt) }\end{array}$ & Importance $\%$ & $\begin{array}{l}\text { Selection } \\
\text { Based on } \\
\text { Weighted }\end{array}$ & $\begin{array}{c}\text { Selection Based } \\
\text { on Characterized } \\
\text { Results }\end{array}$ \\
\hline $\begin{array}{l}\text { Climate change } \\
\text { Human Health }\end{array}$ & DALY * & $4.00 \times 10^{-7}$ & $61 \%$ & $1.13 \times 10^{-2}$ & $27.1 \%$ & $\mathrm{x}$ & $\mathrm{x}$ \\
\hline Ozone depletion & DALY & $8.75 \times 10^{-11}$ & $0 \%$ & $2.48 \times 10^{-6}$ & $0.0 \%$ & & \\
\hline Human toxicity & DALY & $1.95 \times 10^{-8}$ & $3 \%$ & $5.54 \times 10^{-4}$ & $1.3 \%$ & $x$ & $x$ \\
\hline $\begin{array}{l}\text { Photochemical } \\
\text { oxidant formation }\end{array}$ & DALY & $6.21 \times 10^{-11}$ & $0 \%$ & $1.76 \times 10^{-6}$ & $0.0 \%$ & & \\
\hline $\begin{array}{l}\text { Particulate matter } \\
\text { formation }\end{array}$ & DALY & $2.31 \times 10^{-7}$ & $35 \%$ & $6.55 \times 10^{-3}$ & $15.6 \%$ & $\mathrm{x}$ & $\mathrm{x}$ \\
\hline Ionising radiation & DALY & $1.81 \times 10^{-10}$ & $0 \%$ & $5.14 \times 10^{-6}$ & $0.0 \%$ & & \\
\hline $\begin{array}{l}\text { Climate change } \\
\text { Ecosystems }\end{array}$ & species.yr & $2.26 \times 10^{-9}$ & $21 \%$ & $9.81 \times 10^{-4}$ & $2.3 \%$ & $\mathrm{x}$ & $\mathrm{x}$ \\
\hline $\begin{array}{c}\text { Terrestrial } \\
\text { acidification }\end{array}$ & species.yr & $1.88 \times 10^{-11}$ & $0 \%$ & $8.14 \times 10^{-6}$ & $0.0 \%$ & & \\
\hline $\begin{array}{c}\text { Freshwater } \\
\text { eutrophication }\end{array}$ & species.yr & $1.41 \times 10^{-12}$ & $0 \%$ & $6.10 \times 10^{-7}$ & $0.0 \%$ & & \\
\hline $\begin{array}{l}\text { Terrestrial } \\
\text { ecotoxicity }\end{array}$ & species.yr & $3.48 \times 10^{-10}$ & $3 \%$ & $1.51 \times 10^{-4}$ & $0.4 \%$ & & $\mathrm{x}$ \\
\hline $\begin{array}{l}\text { Freshwater } \\
\text { ecotoxicity }\end{array}$ & species.yr & $1.12 \times 10^{-12}$ & $0 \%$ & $4.84 \times 10^{-7}$ & $0.0 \%$ & & \\
\hline Marine ecotoxicity & species.yr & $6.71 \times 10^{-14}$ & $0 \%$ & $2.91 \times 10^{-8}$ & $0.0 \%$ & & \\
\hline $\begin{array}{l}\text { Agricultural land } \\
\text { occupation }\end{array}$ & species.yr & $7.69 \times 10^{-9}$ & $71 \%$ & $3.34 \times 10^{-3}$ & $8.0 \%$ & $\mathrm{x}$ & $\mathrm{x}$ \\
\hline $\begin{array}{l}\text { Urban land } \\
\text { occupation }\end{array}$ & species.yr & $1.20 \times 10^{-10}$ & $1.1 \%$ & $5.18 \times 10^{-5}$ & $0.1 \%$ & & \\
\hline $\begin{array}{l}\text { Natural land } \\
\text { transformation }\end{array}$ & species.yr & $8.50 \times 10^{-11}$ & $0.8 \%$ & $3.68 \times 10^{-5}$ & $0.1 \%$ & & \\
\hline Metal depletion & $\$$ & $2.51 \times 10^{-3}$ & $8 \%$ & $1.40 \times 10^{-3}$ & $3.4 \%$ & $\mathrm{x}$ & $x$ \\
\hline Fossil depletion & $\$$ & $1.28 \times 10^{-2}$ & $38 \%$ & $7.16 \times 10^{-3}$ & $17.1 \%$ & $\mathrm{x}$ & $\mathrm{x}$ \\
\hline Water scarcity HH & DALY & $4.06 \times 10^{-9}$ & $0.6 \%$ & $1.15 \times 10^{-4}$ & $0.3 \%$ & & \\
\hline Water scarcity EQ & species.yr & $3.51 \times 10^{-10}$ & $3.2 \%$ & $1.52 \times 10^{-4}$ & $0.4 \%$ & & $\mathrm{x}$ \\
\hline Water scarcity $\mathrm{R}$ & $\$$ & $1.79 \times 10^{-2}$ & $54 \%$ & $1.00 \times 10^{-2}$ & $24.0 \%$ & $\mathrm{x}$ & $\mathrm{x}$ \\
\hline
\end{tabular}

* DALY: Disability Adjusted Life Years.

Table A3. Monte Carlo Uncertainty analysis.

\begin{tabular}{ccccccccc}
\hline Impact Category & Unit & Mean & Median & SD & CV & 2.50\% & 97.5\% & Std.Err \\
\hline Agricultural land occupation & $\mathrm{m}^{2} \mathrm{a}$ & 0.478 & 0.474 & 0.051 & $11 \%$ & 0.386 & 0.586 & 0.001 \\
\hline Climate change & $\mathrm{kg} \mathrm{CO}$ eq & 0.286 & 0.285 & 0.016 & $6 \%$ & 0.256 & 0.319 & 0.001 \\
\hline Fossil depletion & $\mathrm{kg} \mathrm{oil} \mathrm{eq}$ & 0.077 & 0.077 & 0.008 & $10 \%$ & 0.064 & 0.094 & 0.001 \\
\hline Human toxicity & $\mathrm{kg} \mathrm{1.4-DB} \mathrm{eq}$ & 0.028 & 0.027 & 0.006 & $21 \%$ & 0.017 & 0.040 & 0.002 \\
\hline Metal depletion & $\mathrm{kg} \mathrm{Fe} \mathrm{eq}$ & 0.035 & 0.034 & 0.006 & $18 \%$ & 0.025 & 0.049 & 0.002 \\
\hline Particulate matter formation & $\mathrm{kg} \mathrm{PM10} \mathrm{eq}$ & 0.001 & 0.001 & 0.000 & $6 \%$ & 0.001 & 0.001 & 0.001 \\
\hline Terrestrial ecotoxicity & $\mathrm{kg} \mathrm{1.4-DB} \mathrm{eq}$ & 0.002 & 0.002 & 0.000 & $7 \%$ & 0.002 & 0.003 & 0.001 \\
\hline Water depletion & $\mathrm{m}^{3}$ & 0.084 & 0.088 & 0.051 & $60 \%$ & -0.027 & 0.176 & 0.006 \\
\hline
\end{tabular}

Table A4. Climate Change Inventory substances' contribution to impact category having a threshold of $1 \%$ (cut off $1 \%$ ).

\begin{tabular}{cccc}
\hline Substance & Compartment & Unit & Total \\
\hline \multicolumn{2}{c}{ Total of all compartments } & $\%$ & 100.00 \\
\hline \multicolumn{2}{c}{ Remaining substances } & $\%$ & 0.283 \\
\hline Carbon dioxide, fossil & Air & $\%$ & 77.14 \\
\hline Dinitrogen monoxide & Air & $\%$ & 18.54 \\
\hline Methane. fossil & Air & $\%$ & 4.03 \\
\hline
\end{tabular}


Table A5. Human Toxicity Inventory substances' contribution to impact category having a threshold of $1 \%$ (cut off $1 \%$ ).

\begin{tabular}{cccc}
\hline Substance & Compartment & Unit & Total \\
\hline Total of all compartments & $\%$ & 100 \\
Remaining substances & Air & $\%$ & 6.89 \\
Arsenic & Air & $\%$ & 19.83 \\
Lead & Air & $\%$ & 18.21 \\
Mercury & Soil & $\%$ & 6.68 \\
Zinc & Air & $\%$ & 2.93 \\
Antimony & Water & $\%$ & 3.63 \\
Arsenic & Water & $\%$ & 5.00 \\
Barium & Air & $\%$ & 4.51 \\
Cadmium & Air & $\%$ & 2.80 \\
Chlorine & Soil & $\%$ & 3.22 \\
Chlorpyrifos & Soil & $\%$ & 2.44 \\
Chlorpyrifos methyl & Water & $\%$ & 2.11 \\
Manganese & Water & $\%$ & 1.41 \\
Mercury & Air & $\%$ & 7.82 \\
Vanadium & Air & $\%$ & 1.07 \\
Zinc & &
\end{tabular}

Table A6. Particular Matter formation Inventory substances' contribution to impact category having a threshold of $1 \%$ (cut off $1 \%$ ).

\begin{tabular}{cccc}
\hline Substance & Compartment & Unit & Total \\
\hline Total of all compartments & & $\%$ & 100.00 \\
\hline Remaining substances & & $\%$ & 0.000057 \\
\hline Nitrogen oxides & Air & $\%$ & 28.54 \\
\hline Ammonia & Air & $\%$ & 26.97 \\
\hline Particulates, $<2.5 \mu \mathrm{m}$ & Air & $\%$ & 18.53 \\
\hline Sulphur dioxide & Air & $\%$ & 17.92 \\
\hline $\begin{array}{c}\text { Particulates, }>2.5 \mu \mathrm{m} \\
\text { and }<10 \mu \mathrm{m}\end{array}$ & Air & $\%$ & 8.04 \\
\hline
\end{tabular}

\begin{tabular}{|c|c|c|c|c|c|c|c|c|c|c|}
\hline Ascending & \multirow[b]{3}{*}{ Category } & \multirow[t]{2}{*}{$\begin{array}{l}\begin{array}{l}\text { Climate } \\
\text { change }\end{array} \\
\mathrm{kg} \mathrm{CO}_{\mathrm{eq}}\end{array}$} & $\begin{array}{l}\text { Human } \\
\text { toxicity }\end{array}$ & $\begin{array}{l}\text { Particulate } \\
\text { matter } \\
\text { formation }\end{array}$ & $\begin{array}{l}\text { Terrestrial } \\
\text { ecotoxicity }\end{array}$ & $\begin{array}{l}\text { Agricultural } \\
\text { land } \\
\text { occupation }\end{array}$ & $\begin{array}{l}\text { Water } \\
\text { depletion }\end{array}$ & $\begin{array}{l}\text { Metal } \\
\text { depletion }\end{array}$ & $\begin{array}{l}\text { Fossil } \\
\text { depletion }\end{array}$ & .7 \\
\hline & & & $\mathrm{kg} 1,4$ - DB eq & $\mathrm{qkg}$ PM10 eq & $\mathrm{kg} 1,4$-DBecr & cm2a & $\mathrm{m} 3$ & $\mathrm{kgFeq}$ & $\mathrm{kg}$ oil eq & \\
\hline Process & & Total & Total & Total & Total T & Total & Total & Total T & Total & $\begin{array}{l}\text { Average } \\
\text { contribution }\end{array}$ \\
\hline Total of all processes & & 0,285 & $5 \quad 0,028$ & 0,001 & $1 \quad 0,002$ & 0,478 & $8 \quad 0,085$ & $5 \quad 0,035$ & 0,077 & \\
\hline Agricultural machinery, unspedfied \{GLO\}| market for | Alloc Rec, S & Capital goods/maintenance & 0,034 & 0,0047 & 0,000102 & 0,000003 & 0,00 & 0,0001 & 0,0184 & 0,0086 & $13 \%$ \\
\hline Diesel \{Europe without Switzerland\}| market for | Alloc Rec, S & Fuel/electricity production & 0,009 & 0,0007 & 0,000022 & 0,000001 & 0,000 & 0,0000 & 0,0003 & 0,0196 & $4 \%$ \\
\hline Electricity, low voltage $\{$ GR\}| market for | Alloc Rec, $S$ & Fuel/electricity production & 0,041 & 0,0022 & 0,000081 & 0,000003 & 0,000 & 0,0000 & 0,0007 & 0,0137 & $6 \%$ \\
\hline Irrigation $\{G r\} \mid$ processing | Alloc Rec, $U$, pear project & Operations & 0,002 & 0,0002 & 0,000008 & 0,000000 & 0,000 & 0,1134 & 0,0000 & 0,0000 & $17 \%$ \\
\hline Pear, Coscia, from Timavos, Central Greece, 2011, at fam & Pear orchard & 0,024 & 0,0009 & 0,000121 & 0,000923 & 0,170 & $-0,0024$ & 0,0000 & 0,0000 & $12 \%$ \\
\hline Pear, Coscia, from Timavos, Central Greece, 2012, at fam & Pear orchard & 0,006 & 0,0002 & 0,000024 & 0,000470 & 0,095 & $-0,0027$ & 0,0000 & 0,0000 & $5 \%$ \\
\hline Pear, input 2011, high yield (production 2012) & Pear orchard & 0,013 & 0,0005 & 0,000068 & 0,000515 & 0,095 & $-0,0014$ & 0,0000 & 0,0000 & $7 \%$ \\
\hline Pear, inputs of 2012, low yield (production of 2011) & Pear orchard & 0,005 & 0,0001 & 0,000019 & 0,000375 & 0,076 & $-0,0021$ & 0,0000 & 0,0000 & $4 \%$ \\
\hline Pesticide/Herbidide tractor use for pear orchard in Greece, $U$, pear project & Operations & 0,025 & 0,001 & 0,000 & 0,000 & 0,000 & 0,000 & 0,000 & 0,000 & $3 \%$ \\
\hline Tractor, 4-wheel, agricultural \{GLO\}| market for | Alloc Rec, S & Capital goods/maintenance & 0,021 & 0,0050 & 0,000052 & 0,000002 & 0,001 & 0,0001 & 0,0085 & 0,0065 & $8 \%$ \\
\hline Urea, as $\mathrm{N}\{$ RER\}| production | Alloc Rec, S & Fertiliser production & 0,011 & 0,002 & 0,000 & 0,000 & 0,000 & 0,000 & 0,001 & 0,004 & $3 \%$ \\
\hline
\end{tabular}

Figure A1. Contribution processes with cut off (till 2\%). 
Table A7. Comparison of GLO pear production with the GR pear production.

\begin{tabular}{ccccc}
\hline Impact Category & Unit & $\begin{array}{c}\text { Total Pear \{GLO\}| } \\
\text { Production Alloc Rec. S }\end{array}$ & $\begin{array}{c}\text { Total Pear Greece } \\
\text { Production }\end{array}$ & $\begin{array}{c}\text { \% Total Pear Greece/Total } \\
\text { Pear GLO }\end{array}$ \\
\hline Climate change & $\mathrm{kg} \mathrm{CO}_{2}$ eq & 0.3157 & 0.282 & $89 \%$ \\
\hline Human toxicity & $\mathrm{kg} \mathrm{1.4-DB} \mathrm{eq}$ & 0.0198 & 0.026 & $132 \%$ \\
\hline Particulate matter formation & $\mathrm{kg} \mathrm{PM10} \mathrm{eq}$ & 0.0007 & 0.001 & $119 \%$ \\
\hline Terrestrial ecotoxicity & $\mathrm{kg} \mathrm{1.4-DB} \mathrm{eq}$ & 0.0004 & 0.002 & $609 \%$ \\
\hline Agricultural land occupation & $\mathrm{m}^{2} \mathrm{a}$ & 0.3684 & 0.486 & $132 \%$ \\
\hline Water depletion & $\mathrm{m}^{3}$ & 0.0123 & 0.087 & $705 \%$ \\
\hline Metal depletion & $\mathrm{kg} \mathrm{Fe} \mathrm{eq}$ & 0.0124 & 0.035 & $285 \%$ \\
\hline Fossil depletion & $\mathrm{kg}$ oil eq & 0.0816 & 0.076 & $93 \%$ \\
\hline
\end{tabular}

\section{References}

1. Lal, R. Soil carbon sequestration to mitigate climate change. Geoderma 2004, 123, 1-22. [CrossRef]

2. de Moraes Sá, J.C.; Lal, R.; Cerri, C.C.; Lorenz, K.; Hungria, M.; de Faccio Carvalho, P.C. Low-carbon agriculture in South America to mitigate global climate change and advance food security. Environ. Int. 2017, 98, 102-112. [CrossRef]

3. Pimentel, D. Soil erosion: A food and environmental threat. Environ. Dev. Sustain. 2006, 8, 119-137. [CrossRef]

4. Montgomery, D.R. Soil erosion and agricultural sustainability. Proc. Natl. Acad. Sci. USA 2007, 104, 13268-13272. [CrossRef] [PubMed]

5. Biddoccu, M.; Guzmán, G.; Capello, G.; Thielke, T.; Strauss, P.; Winter, S.; Zaller, J.G.; Nicolai, A.; Cluzeau, D.; Popescu, D.; et al. Evaluation of soil erosion risk and identification of soil cover and management factor (C) for RUSLE in European vineyards with different soil management. Int. Soil Water Conserv. Res. 2020. [CrossRef]

6. Morison, J.I.L.; Baker, N.R.; Mullineaux, P.M.; Davies, W.J. Improving water use in crop production. Philos. Trans. R. Soc. B Biol. Sci. 2008, 363. [CrossRef]

7. Zahoor, S.A.; Ahmad, S.; Ahmad, A.; Wajid, A.; Khaliq, T.; Mubeen, M.; Hussain, S.; Din, M.S.U.; Amin, A.; Awais, M.; et al. Improving water use efficiency in agronomic crop production. In Agronomic Crops; Management Practices; Springer: Singapore, 2019; Volume 2, pp. 13-29. [CrossRef]

8. Juraske, R.; Sanjuán, N. Life cycle toxicity assessment of pesticides used in integrated and organic production of oranges in the Comunidad Valenciana, Spain. Chemosphere 2011, 82, 956-962. [CrossRef]

9. Stoate, C.; Báldi, A.; Beja, P.; Boatman, N.D.; Herzon, I.; van Doorn, A.; de Snoo, G.R.; Rakosy, L.; Ramwell, C. Ecological impacts of early 21st century agricultural change in Europe-A review. J. Environ. Manag. 2009, 91, 22-46. [CrossRef]

10. de Souza, R.M.; Seibert, D.; Quesada, H.B.; de Jesus Bassetti, F.; Fagundes-Klen, M.R.; Bergamasco, R. Occurrence, impacts and general aspects of pesticides in surface water: A review. Process Saf. Environ. Prot. 2020, 135, 22-37. [CrossRef]

11. Henryson, K.; Kätterer, T.; Tidåker, P.; Sundberg, C. Soil $\mathrm{N}_{2} \mathrm{O}$ emissions, N leaching and marine eutrophication in life cycle assessment-A comparison of modelling approaches. Sci. Total Environ. 2020, 725, 138332. [CrossRef]

12. Sarkar, D.; Kar, S.K.; Chattopadhyay, A.; Shikha; Rakshit, A.; Tripathi, V.K.; Dubey, P.K.; Abhilash, P.C. Low input sustainable agriculture: A viable climate-smart option for boosting food production in a warming world. Ecol. Indic. 2020, 115, 106412. [CrossRef]

13. Tasca, A.L.; Nessi, S.; Rigamonti, L. Environmental sustainability of agri-food supply chains: An LCA comparison between two alternative forms of production and distribution of endive in northern Italy. J. Clean. Prod. 2017, 140, 725-741. [CrossRef]

14. Kulak, M.; Nemecek, T.; Frossard, E.; Gaillard, G. How eco-efficient are low-input cropping systems in Western Europe, and what can be done to improve their eco-efficiency? Sustainability 2013, 5, 3722-3743. [CrossRef]

15. Bacenetti, J.; Paleari, L.; Tartarini, S.; Vesely, F.M.; Foi, M.; Movedi, E.; Ravasi, R.A.; Bellopede, V.; Durello, S.; Ceravolo, C.; et al. May smart technologies reduce the environmental impact of nitrogen fertilization? A case study for paddy rice. Sci. Total Environ. 2020, 715, 136956. [CrossRef] 
16. Zude-Sasse, M.; Fountas, S.; Gemtos, T.A.; Abu-Khalaf, N. Applications of precision agriculture in horticultural crops. Eur. J. Hortic. Sci. 2016, 81, 78-90. [CrossRef]

17. Zaman, Q.U.; Schumann, A.W.; Miller, W.M. Variable rate nitrogen application in Florida citrus based on ultrasonically-sensed tree size. Appl. Eng. Agric. 2005, 21, 331-335. [CrossRef]

18. Li, A.; Duval, B.D.; Anex, R.; Scharf, P.; Ashtekar, J.M.; Owens, R.P.; Ellis, C. A Case Study of Environmental Benefits of Sensor-Based Nitrogen Application in Corn. J. Environ. Qual. 2016, 45, 675-683. [CrossRef]

19. Vatsanidou, A.; Nanos, G.D.; Fountas, S.; Baras, J.; Castrignano, A.; Gemtos, T.A. Nitrogen replenishment using variable rate application technique in a small hand-harvested pear orchard. Span. J. Agric. Res. 2017, 15, e0209. [CrossRef]

20. Liakos, V.; Smith, E.; Fountas, S.; Nanos, G.; Kalfountzos, D.; Gemtos, T. On-Farm Evaluation of Variable Rate Fertiliser Applications Using Yield-Based Mathematical Formulae in a Greek Apple Orchard. Int. J. Fruit Sci. 2020, 1-18. [CrossRef]

21. Johnson, C.K.; Mortensen, D.A.; Wienhold, B.J.; Shanahan, J.F.; Doran, J.W. Site-specific management zones based on soil electrical conductivity in a semiarid cropping system. Agron. J. 2003, 95, 303-315. [CrossRef]

22. Heege, H.J. Precision in Crop Farming: Site Specific Concepts and Sensing Methods: Applications and Results; Springer Science and Business Media: Dordrecht, The Netherlands, 2013. [CrossRef]

23. Basso, B.; Dumont, B.; Cammarano, D.; Pezzuolo, A.; Marinello, F.; Sartori, L. Environmental and economic benefits of variable rate nitrogen fertilization in a nitrate vulnerable zone. Sci. Total Environ. 2016, 545-546, 227-235. [CrossRef] [PubMed]

24. van Evert, F.K.; Gaitán-Cremaschi, D.; Fountas, S.; Kempenaar, C. Can precision agriculture increase the profitability and sustainability of the production of potatoes and olives? Sustainability 2017, 9, 1863. [CrossRef]

25. Bongiovanni, R.; Lowenberg-Deboer, L. Precision Agriculture and Sustainability. Prec. Agric. 2004, 5, 359-387. [CrossRef]

26. English, C.B.; Mahajanashetti, S.B.; Roberts, R.K. Economic and Environmental Benefit of Variable Rate Application of Nitrogen to Corn Fields: Role of Variability and Weather. Selected Paper. In Proceedings of the American Agricultural Economics Association Meeting, Nashville, TN, USA, 8-11 August 1999.

27. Kholsa, R.; Shaver, T.M.; Reich, R.M.; Gangloff, W.J. Evaluating Management Zones for Variable Rate Nitrogen Management in Corn. In Proceedings of the Third International Conference on Geospatial Information in Agriculture and Forestry, Denver, CO, USA, 5-7 November 2001.

28. Roberts, R.; English, B.; Mahajanashetti, S. Environmental and economic effects of spatial variability and weather. In Proceedings of the 3rd European Conference on Precision Agriculture, Montpellier, France, 18-20 June 2001; pp. 545-550.

29. Basso, B.; Sartori, L.; Cammarano, D.; Fiorentino, C.; Grace, R.P.; Fountas, S.; Sorensen, A.C. Environmental and economic evaluation of $\mathrm{N}$ fertiliser rates in a maize crop in Italy: A spatial and temporal analysis using crop models. Biosyst. Eng. 2012, 113, 103-111. [CrossRef]

30. Balafoutis, A.T.; Koundouras, S.; Anastasiou, E.; Fountas, S.; Arvanitis, K. Life cycle assessment of two vineyards after the application of precision viticulture techniques: A case study. Sustainability 2017, 9, 1997. [CrossRef]

31. Guinée, J.B. Handbook on life cycle assessment operational guide to the ISO standards. Int. J. Life Cycle Assess. 2002, 7, 311-313. [CrossRef]

32. Ponsioen, T.C.; Van Der Werf, H.M.G. Five propositions to harmonize environmental footprints of food and beverages. J. Clean. Prod. 2017, 153, 457-464. [CrossRef]

33. Mila i Canals, L.; Burni, G.M.; Cowell, S.J. Evaluation of the environmental impacts of apple production using Life Cycle Assessment (LCA): Case study in New Zealand. Agric. Ecosyst. Environ. 2006, 114, $226-238$. [CrossRef]

34. Beccali, M.; Cellura, M.; Iudicello, M.; Mistretta, M. Resources consumption and environmental impacts of the agro-food sector. Life cycle assessment of Italian citrus based products. J. Environ. Manag. 2009, 43, 707-724. [CrossRef]

35. Ingwersen, W.W. Life cycle assessment of fresh pineapple from Costa Rica. J. Clean. Prod. 2012, 35, 152-163. [CrossRef]

36. Ingrao, C.; Matarazzo, A.; Tricase, C.; Clasadonte, M.T.; Huisingh, D. Life Cycle Assessment for highlighting environmental hotspots in Sicilian peach production systems. J. Clean. Prod. 2015, 92, 109-120. [CrossRef] 
37. Vinyes, E.; Gasol, C.M.; Asin, L.; Alegre, S.; Muñoz, P. Life Cycle Assessment of multiyear peach production. J. Clean. Prod. 2015, 104, 68-79. [CrossRef]

38. Liu, Y.; Langer, V.; Høgh-Jensen, H.; Egelyng, H. Life Cycle Assessment of fossil energy use and greenhouse gas emissions in Chinese pear production. J. Clean. Prod. 2010, 18, 1423-1430. [CrossRef]

39. ISO 14040. Environmental Management_LCA—Principles and Framework; International Organization for Standardization: Geneva, Switzerland, 2006.

40. ISO 14044. Environmental Management_LCA—Requirements and Guidelines; International Organization for Standardization: Geneva, Switzerland, 2006.

41. SimaPro, version 8.0.4.30; Consultants software; PRé: Amersfoort, The Netherlands, 2016.

42. USDA-NRCS. Keys to Soil Taxonomy, 8th ed.; USDA-Natural Resources Conservation Service: Washington, DC, USA, 1998.

43. Yusoff, S.; Hansen, S.B. Feasibility study of performing a life cycle assessment on crude palm oil production in Malaysia. Int. J. Life Cycle Assess. 2007, 12, 50-58.

44. Rocco, M. Accounting for human labour in LCA: A novel Input-Output approach. In Life Cycle Thinking, Sostenibilità ed Economia Circolare, Proceedings of the V Conference of the Italian LCA Network, Ravenna, Italy, 23-24 June 2016; Loprieno, A.D., Scalbi, S., Righi, S., Eds.; ENEA: Rome, Italy, 2016.

45. Cerruti, A.K.; Bagliani, M.; Beccaro, G.L.; Bounous, G. Application of ecological footprint analysis on nectarine production: Methodological issues and results from a case study in Italy. J. Clean. Prod. 2010, 18, 771-776. [CrossRef]

46. Ecoinvent Database. Ecoinvent Data v3.1, Life Cycle Inventory Database. Available online: https://www. ecoinvent.org/database/older-versions/ecoinvent-31/ecoinvent-31.html/. (accessed on 21 July 2020).

47. Weidema, B.P.; Meeusen, M.J.G. Agricultural Data for Life Cycle Assessments; Report 2.00.01; Agricultural Economics Research Institute (LEI): The Hague, The Netherlands, 1999; ISBN 90-5242-563-9.

48. Nemecek, T.; Bengoa, X.; Lansche, J.; Mouron, P.; Rossi, V.; Humbert, S. Methodological Guidelines for the Life Cycle Inventory of Agricultural Products; Version 2.0.; World Food LCA Database (WFLDB) Quantis and Agroscope: Lausanne/Zurich, Switzerland, 2014.

49. IPCC Revised Good Practice Guidelines for Greenhouse Gas Inventories. Available online: https://www. ipcc-nggip.iges.or.jp/public/2006gl/vol4.html (accessed on 21 July 2020).

50. Nemecek, T.J.; Schnetzer, J.; Reinhard, J. Updated and harmonised greenhouse gas emissions for crop inventories. Int. J. Life Cycle Assess. 2014, 21, 1361-1378. [CrossRef]

51. Nemecek, T.; Schnetzer, J. Methods of Assessment of Direct Field Emissions for LCIs of Agricultural Production Systems, Data v3.0; Agroscope, ART CH-8046; Reckenholz-Tänikon Research Station: Zurich, Switzerland, 2012.

52. Vatsanidou, A. Environmental Assessment of New Technologies: Two Case Studies, in Pear Orchard and in Energy Crops. Ph.D. Thesis, University of Thessaly, Volos, Greece, 2017.

53. Goedkoop, M.; Huijbregts, M. Characterisation. In ReCiPe 2008; VROM: The Hague, The Netherlands, 2013; pp. 4-20.

54. Pfister, S.; Saner, D.; Koehler, A. The environmental relevance of freshwater consumption in global power production. Int. J. Life Cycle Assess. 2011, 16, 580-591. [CrossRef]

55. Stoessel, F.; Juraske, R.; Pfister, S.; Hellweg, S. Life Cycle Inventory and Carbon and Water Food Print of Fruits and Vegetables: Application to a Swiss Retailer. Environ. Sci. Technol. 2012, 46, 3253-3262. [CrossRef]

56. Webster, A.D. Factors influencing the flowering, fruit set and fruit growth of European pears. Acta Horticult. 2002, 596, 699-709. [CrossRef]

(C) 2020 by the authors. Licensee MDPI, Basel, Switzerland. This article is an open access article distributed under the terms and conditions of the Creative Commons Attribution (CC BY) license (http://creativecommons.org/licenses/by/4.0/). 